\title{
Systematic Review \\ Prevalence of Developmental Dyslexia in Primary School Children: A Systematic Review and Meta-Analysis
}

\author{
Liping Yang ${ }^{1,2}$, Chunbo Li ${ }^{3,4,5}$, Xiumei Li $^{1,2}$, Manman Zhai ${ }^{1,2}$, Qingqing An ${ }^{1,6}$, You Zhang ${ }^{1,6}$, Jing Zhao ${ }^{7,8, *}$ \\ and Xuchu Weng ${ }^{1,6, *}$
}

check for updates

Citation: Yang, L.; Li, C.; Li, X.; Zhai, M.; An, Q.; Zhang, Y.; Zhao, J.; Weng, X. Prevalence of Developmental Dyslexia in Primary School Children: A Systematic Review and Meta-Analysis. Brain Sci. 2022, 12, 240. https://doi.org/ $10.3390 /$ brainsci12020240

Academic Editors: Angela J. Fawcett and Maria Pia Bucci

Received: 18 December 2021

Accepted: 6 February 2022

Published: 10 February 2022

Publisher's Note: MDPI stays neutral with regard to jurisdictional claims in published maps and institutional affiliations.

Copyright: (C) 2022 by the authors. Licensee MDPI, Basel, Switzerland. This article is an open access article distributed under the terms and conditions of the Creative Commons Attribution (CC BY) license (https:// creativecommons.org/licenses/by/ $4.0 /)$.
1 Key Laboratory of Brain, Cognition and Education Sciences, Ministry of Education, Guangzhou 510631, China; yang-psy@foxmail.com (L.Y.); 2018022967@m.scnu.edu.cn (X.L.); zhaimm@m.scnu.edu.cn (M.Z.); 2019023044@m.scnu.edu.cn (Q.A.); 2019023159@m.scnu.edu.cn (Y.Z.)

2 School of Psychology, South China Normal University, Guangzhou 510631, China

3 Shanghai Key Laboratory of Psychotic Disorders, Shanghai Mental Health Center, Shanghai Jiao Tong University School of Medicine, Shanghai 200030, China; licb@smhc.org.cn

4 CAS Center for Excellence in Brain Science and Intelligence Technology (CEBSIT), Chinese Academy of Sciences, Shanghai 200031, China

5 Institute of Psychology and Behavioral Science, Shanghai Jiao Tong University, Shanghai 200030, China

6 Institute for Brain Research and Rehabilitation, South China Normal University, Guangzhou 510631, China

7 Institutes of Psychological Sciences, Hangzhou Normal University, Hangzhou 311121, China

8 Zhejiang Key Laboratory for Research in Assessment of Cognitive Impairments, Hangzhou 311121, China

* Correspondence: zhaojing561@126.com (J.Z.); wengxc@psych.ac.cn (X.W.)

\begin{abstract}
Background: Developmental dyslexia (DD) is a specific learning disorder concerning reading acquisition that may has a lifelong negative impact on individuals. A reliable estimate of the prevalence of DD serves as the basis for diagnosis, intervention, and evidence-based health resource allocation and policy-making. Hence, the present meta-analysis aims to generate a reliable prevalence estimate of DD worldwide in primary school children and explore the potential variables related to that prevalence. Methods: Studies from the 1950s to June 2021 were collated using a combination of search terms related to DD and prevalence. Study quality was assessed using the STROBE guidelines according to the study design, with study heterogeneity assessed using the $I^{2}$ statistic, and random-effects meta-analyses were conducted. Variations in the prevalence of DD in different subgroups were assessed via subgroup meta-analysis and meta-regression. Results: The pooled prevalence of DD was 7.10\% (95\% CI: 6.27-7.97\%). The prevalence in boys was significantly higher than that in girls (boys: 9.22\%, 95\%CI, 8.07-10.44\%; girls: 4.66\%, 95\% CI, 3.84-5.54\%; $p<0.001$ ), but no significant difference was found in the prevalence across different writing systems (alphabetic scripts: $7.26 \%$, 95\%CI, 5.94-8.71\%; logographic scripts: $6.97 \%, 95 \% \mathrm{CI}, 5.86-8.16 \% ; p>0.05$ ) or across different orthographic depths (shallow: 7.13\%, 95\% CI, 5.23-9.30\%; deep: 7.55\%, 95\% CI, 4.66-11.04\%; $p>0.05)$. It is worth noting that most articles had small sample sizes with diverse operational definitions, making comparisons challenging. Conclusions: This study provides an estimation of worldwide DD prevalence in primary school children. The prevalence was higher in boys than in girls but was not significantly different across different writing systems.
\end{abstract}

Keywords: developmental dyslexia; prevalence; primary school children

\section{Introduction}

Developmental dyslexia (DD) is a specific impairment characterized by severe and persistent problems in the acquisition of reading skills; these problems are not caused by mental age, visual acuity problems, or inadequate schooling [1,2]. DD, also referred to as specific reading disability or specific reading disorder, is by far the most common type of learning disability, accounting for approximately $80 \%$ of all learning disabilities [3]. Due to their frustration with reading, a great number of dyslexic children are also at increased risk 
of academic and social problems [4]. These children often have higher reading anxiety [5-7], lower positive well-being [8], and experience negative attitudes [6,9].

Typically, children begin to be formally taught to read after entering primary school, and their word-reading ability reaches adult-like levels by the end of primary school [10]. Diagnosis of DD is normally achieved after a child begins structured schooling [11]. The primary school is, thus, an important point at which early literacy screening and interventions can help to identify potential reading difficulties and address risk factors [12,13]. Therefore, the present study focuses on DD in primary school children.

Dyslexia is fairly widespread but demonstrates uncertain prevalence, ranging from $5 \%$ to $17.5 \%[14,15]$, and the variability of prevalence may be related to several factors. First, different operational definitions may result in a different prevalence. The common sets of the cut-off for reading achievement are 1 and 1.5 standard deviations (SD) below the mean for the same age [16-18]. Second, environmental variables (e.g., regions, socioeconomic status) and other factors (e.g., grade, sub-deficit) may also influence each child's risk of dyslexia.

Finally, it is particularly interesting to ask whether and in what way orthographic depth influences the prevalence of DD. On the one hand, logographic scripts may yield different prevalence estimates relative to alphabetic scripts. In alphabetic scripts in which the letters represent phonemes, the prevalence of DD was reported to range from $2.28 \%$ to $12.70 \%$ [19,20], even as high as $15 \%$ and $19.90 \%$ [21,22]. Unlike alphabetic scripts, logographic scripts such as Chinese have special language characteristics: (1) the smallest written units are characters representing monosyllabic morphemes; and (2) grapheme to phoneme mappings are created in an arbitrary way [23-25]. As logographic scripts, such as Chinese, require the memorization of picture-like characters by rote, it was previously believed that the script presented little or no difficulty in reading [26] until 1982, when Stevenson et al. [27] reported for the first time that DD did exist among Chinese and Japanese readers. On the other hand, even within alphabetic writing systems, such systems differ in terms of orthographic depths. According to the orthographic depth hypothesis (ODH) [28], shallower orthographies are easier to learn than deeper ones. For children, it is easier to learn how to map letters onto phonological forms that are known from speech in the shallower orthographies, where in units in the written language reliably correspond to units in the spoken language. In contrast, the other two theories (the psycholinguistic grain size theory and the grapholinguistic equilibrium hypothesis) propose that the incidence of DD will be very similar across both consistent and inconsistent orthographies but that its manifestation might differ according to orthographic consistency $[29,30]$.

In addition, the gender ratio of DD is the subject of an ongoing debate [31-33]. Most studies reported that more boys suffered from DD than girls, and the gender ratio of boys to girls was about 3:1 [34-36], but some studies found no differences in the prevalence of DD between boys and girls [18,31]. The latter interpreted the over-representation of boys in DD prevalence to be a result of bias in behavioral observation [37]. To address this problem, we conducted a subgroup analysis of gender prevalence.

Taken together, a large number of previous studies have assessed the prevalence of DD in primary school children, but the results are largely mixed. More importantly, the previous review articles did not thoroughly discuss the prevalence of Chinese DD [14,15], although the number of Chinese users is large and widely distributed. Therefore, it is necessary to include Chinese for meta-analysis.

The present study thus aimed to conduct a systematic and meta-analytical review of previous studies that reported the prevalence of DD in children in primary school. More specifically, the present study aimed to address two issues: (a) what is the prevalence of childhood DD worldwide; and (b) whether the prevalence of DD varies according to gender, writing system, and other variables. 


\section{Materials and Methods}

\subsection{Search Strategy and Selection Criteria}

This systematic review and meta-analysis was conducted in accordance with the preferred reporting items for systematic reviews and meta-analyses (PRISMA) reporting guidelines [38]. The protocol of this study was registered in PROSPERO (registration number: CRD42021232958).

Looking at studies from the 1950s to 10 June 2021, two researchers (X.L. and M.Z.) independently conducted a literature search of the China National Knowledge Infrastructure, Wanfang, CQ-VIP, the China Hospital Knowledge Database, EBSCO host, ProQuest, PubMed, Web of Science, the OATD database, Cochrane, Springerlink and EMBASE, using a combination of search terms related to DD (dyslexia, reading disability, reading disorder, or learning disability), and prevalence (prevalence, detectable rate, incidence rate, or epidemiology). Then, a search of the reference lists of the studies included in the first step was performed to complement our database searches. No language or time restrictions were applied. The full search strategies for different bibliographic databases are presented in Table A1.

The study inclusion criteria were that: (i) participants consisted of primary school students (age range: 6-13 years; grade range: 1st-6th); (ii) subjects were recruited through probability sampling methods; (iii) studies included DD prevalence as a main or secondary outcome; (iv) measures with good psychometrics were used to assess the symptoms of DD; (v) no restrictions in terms of languages and published periods. For studies involving both adolescents and primary school children, the data of the primary group had to be able to be disaggregated. For multiple articles that used data from the same investigation (duplicates), only the articles with the most comprehensive results or the largest sample size were kept.

The following studies were excluded: (i) those including non-primary school students as participants; (ii) case-control studies, randomized clinical trials, review articles, and editorials; (iii) gray literature-material published by governments, organizations, and industrial or commercial entities for non-academic purposes, conference proceedings, and abstracts; (iv) no reports on DD prevalence were included in the articles; (v) studies were of specific sub-populations of participants (e.g., participants with acute or chronic disease); (vi) the articles could not be retrieved in full-text form through online databases, via library requests or email correspondence with the authors of the studies; (vii) the articles provided insufficient data regarding sample information.

After removing duplicates from different bibliographic databases, the two researchers (X.L. and M.Z.) independently screened the titles and abstracts of all retrieved records from the literature search. Then, the same two researchers assessed the eligibility of potentially relevant articles in the full text against the selection criteria. A consensus was reached for any disagreements through discussion, or the matter was decided by the other two researchers (L.Y. and J.Z.).

\subsection{Data Extraction and Quality Assessment}

Data were independently extracted from the included articles by two researchers (Q.A. and Y.Z.). The collected information included title, first author, year of publication, country, study design, sampling strategy, diagnostic materials, diagnostic criteria, sample size, the number of participants screened as DD, and prevalence estimate. The regions of study location were designated as African Region, Region of the Americas, Southeast Asia Region, European Region, Eastern Mediterranean Region, and Western Pacific Region according to the World Health Organization (WHO) criteria and as high-income countries and low- and middle-income countries according to the World Bank (WB) criteria.

We rated the quality of included articles according to the Strengthening the Reporting of Observational Studies in Epidemiology (STROBE) reporting guideline in several dimensions: sample population, sample size, participation rate, outcome assessment, and analytical methods (Table A2) [39]. 


\subsection{Overall Pooled Prevalence of DD}

Before pooling the prevalence estimates, the variance of raw prevalence from each included study was stabilized, using the Freeman-Tukey double arc-sine transformation [40]. All estimates were presented after back transformation. We assessed the heterogeneity of prevalence estimates among studies using the Cochran $\mathrm{Q}$ test and $I^{2}$ index $[41,42]$. For the Cochran $Q$ test, $p<0.05$ represented significant heterogeneity. For the $I^{2}$ index, values of $25 \%$ or lower corresponded to low degrees of heterogeneity, $26 \%$ to $50 \%$, to moderate degrees of heterogeneity, and values greater than $50 \%$ to high degrees of heterogeneity [41,42].

Because of high heterogeneity (as expected and observed), a random-effect metaanalysis (following the DerSimonian and Laird method) was used to calculate the overall pooled prevalence of DD with $95 \%$ CIs throughout this study [40]. To examine whether single studies had a disproportionally excessive influence, we applied a "leave-1-out" sensitivity analysis for each meta-analysis [43]. Publication bias in the meta-analysis was detected qualitatively by a visual inspection of funnel plots and quantitatively by the Egger linear regression test and the Begg rank correlation test when more than 10 estimates were available in a single analysis [44-46].

\subsection{Subgroup Meta-Analysis and Meta-Regression of DD Prevalence}

We conducted subgroup meta-analyses to determine potential sources of heterogeneity. As a rule, at least three studies should be available per subgroup.

Multiple data points were generally reported in a single study. To assess the associations among various sample characteristics and the prevalence of $\mathrm{DD}$, we first conducted a univariable meta-regression, if possible, followed by a multi-variable meta-regression [47]. As a rule, at least 10 data points should be available for each variable in univariable metaregression, and 20 in multivariable meta-regression [48,49]. Data were analyzed using RStudio, version 2021.09.1-372 (R Foundation for Statistical Computing).

\section{Results}

\subsection{Study Selection and Characteristics}

As outlined in Figure 1, our initial literature search identified a total of 6564 records. After applying the eligibility criteria, a final set of 56 articles, featuring 58 studies, were included in our quantitative synthesis. A list of the 56 included articles is given in Table A3.

The detailed characteristics of the included articles can be found in Table A3. In all, 41 of the 58 studies $(70.69 \%)$ reported prevalence data for both boys and girls. Of the 58 studies, 27 (46.55\%) were conducted among children using alphabetic scripts, while $31(53.45 \%)$ were conducted among children using alphabetic scripts. In addition, grade 3 was the most-studied grade $(21,36.21 \%)$ and random sampling was the most-used method $(37,63.79 \%)$, while only four studies $(6.90 \%)$ had a sample size greater than 10,000 . Moreover, more than half of the 58 studies $(33,56.90 \%)$ were conducted in the Western Pacific area and in middle-income countries $(40,68.97 \%)$.

\subsection{Pooled Prevalence of $D D$}

Table 1 illustrates the results of overall and subgroup meta-analyses. Regarding DD, the pooled prevalence was $7.10 \%$ (95\% CI: $6.27-7.97 \%)$, as ascertained using random-effects meta-analysis (Figure 2). 


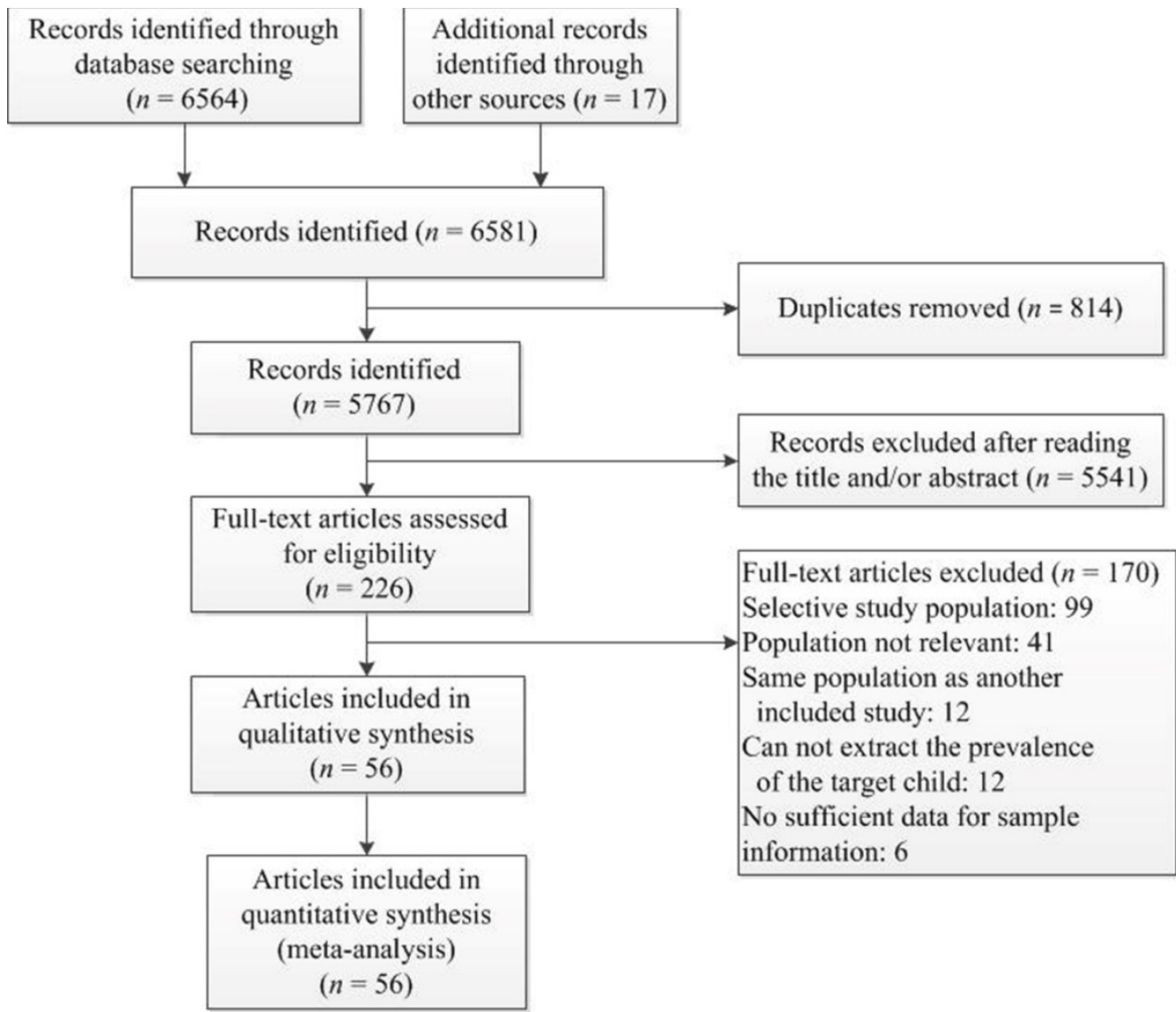

Figure 1. PRISMA flow diagram of literature search and study selection.

\subsection{Sensitivity Analysis and Publication Bias}

The "leave-1-out" sensitivity analysis showed that the pooled prevalence of DD varied from $6.93 \%$ (95\% CI: $6.13-7.78 \%$ ) to $7.21 \%$ (95\% CI: $6.38-8.09 \%$ ) after removing a single study at one time (Figure A1), indicating that no individual study significantly influenced the overall pooled prevalence in the meta-analysis. Publication bias was established based on the funnel plot (Figure A2), Egger test $(t=6.25, p<0.001)$, and Begg test $(z=1.96$, $p=0.05)$.

\subsection{Subgroup Meta-Analysis and Meta-Regression of DD}

Table 1 and Figure 3 showed the prevalence of DD in different genders, writing systems, operational definitions, grades, sample sizes, sampling methods, sub-deficits, WHO regions, WB regions, and the forest plot for the difference in these factors.

There were significant differences in prevalence in terms of gender, operational definitions, and sample size. Specifically, the prevalence of DD was higher in boys $(9.22 \%$; $95 \% \mathrm{CI}$ : 8.07-10.44\%) than in girls (4.66\%; 95\% CI: 3.84-5.54\%) $(p<0.001)$. In addition, a difference in DD prevalence was found among various operational definitions and sample sizes. The results of the post hoc analyses showed that DD prevalence was significantly lower when reporting $1.5 \mathrm{SD}$ and $2 \mathrm{SD}$ as the cut-off values than without reporting the cut-off value (1.5 SD: 5.36\%, 95\% CI, 4.28-6.55\%; 2 SD: 5.32\%, 95\% CI, 4.56-6.13\%; without reporting SD: $9.10 \%, 95 \%$ CI, 7.18-11.21\%; both $p<0.05$, FDR-corrected). The prevalence in a large sample (more than 10,000) was significantly lower than that in smaller samples (500-1000 and 1000-1500) (10,000-: 3.13\%, 95\% CI, 2.32-4.06\%; 500-1000: 8.43\%, 95\% CI, 6.83-10.18\%; 1000-1500: 8.25\%, 95\% CI, 6.43-10.27\%; both $p=0.09$, FDR-corrected). However, there was no significant difference in the prevalence between the two smaller samples $(p>0.05)$. Univariate and multivariate regression results also showed that the subgroup of the largest sample size reported the lowest prevalence of DD. 
Table 1. Prevalence of DD using random-effects meta-analysis and subgroup meta-analysis.

\begin{tabular}{|c|c|c|c|c|c|c|c|}
\hline \multirow{2}{*}{ Variable } & \multirow{2}{*}{$\begin{array}{l}\text { No. of } \\
\text { Studies }\end{array}$} & \multirow{2}{*}{$\begin{array}{c}\text { Prevalence } \\
(95 \% \text { CI) }\end{array}$} & \multirow{2}{*}{$I^{2}, \%$} & \multicolumn{4}{|c|}{$p$-Value } \\
\hline & & & & Q Test & Egger Test & Begg Test & $\begin{array}{l}\text { Subgroup } \\
\text { Difference }\end{array}$ \\
\hline \multicolumn{8}{|l|}{ Global Analysis for DD } \\
\hline DD & 56 & $7.10[6.27 ; 7.97]$ & 97.60 & $<0.001$ & $<0.001$ & 0.05 & NA \\
\hline \multicolumn{8}{|l|}{ Gender } \\
\hline boy & 41 & $9.22[8.07 ; 10.44]$ & 95.80 & $<0.001$ & $<0.001$ & 0.35 & \multirow[b]{2}{*}{$<0.001$} \\
\hline girl & 41 & $4.66[3.84 ; 5.54]$ & 95.20 & $<0.001$ & $<0.001$ & 0.17 & \\
\hline \multicolumn{8}{|l|}{ Writing system } \\
\hline alphabetic scripts & 27 & $7.26[5.94 ; 8.71]$ & 98.10 & $<0.001$ & $<0.05$ & 0.06 & \multirow{2}{*}{0.74} \\
\hline logographic writing system & 31 & $6.97[5.86 ; 8.16]$ & 96.90 & $<0.001$ & $<0.001$ & 0.27 & \\
\hline \multicolumn{8}{|l|}{ Orthography depth } \\
\hline shallow orthography & 17 & $7.13[5.23 ; 9.30]$ & 98.30 & $<0.001$ & $<0.05$ & 0.19 & \multirow[b]{2}{*}{0.83} \\
\hline deep orthography & 10 & $7.55[4.66 ; 11.04]$ & 97.80 & $<0.001$ & $<0.05$ & 0.24 & \\
\hline \multicolumn{8}{|l|}{ Operational definition } \\
\hline $1 \mathrm{SD}$ & 11 & $7.10[4.51 ; 10.22]$ & 98.40 & $<0.001$ & $<0.01$ & 0.14 & \multirow{4}{*}{$<0.01$} \\
\hline $1.5 \mathrm{SD}$ & 6 & $5.36[4.28 ; 6.55]$ & 87.70 & $<0.001$ & NA & NA & \\
\hline $2 \mathrm{SD}$ & 18 & $5.32[4.56 ; 6.13]$ & 93.70 & $<0.001$ & $<0.01$ & 0.18 & \\
\hline Without reporting SD & 23 & $9.10[7.18 ; 11.21]$ & 97.20 & $<0.001$ & 0.03 & 0.58 & \\
\hline \multicolumn{8}{|l|}{ Grade } \\
\hline 1 & 4 & $7.59[2.65 ; 14.72]$ & 96.40 & $<0.001$ & NA & NA & \multirow{6}{*}{0.40} \\
\hline 2 & 7 & $4.88[2.94 ; 7.28]$ & 92.00 & $<0.001$ & NA & NA & \\
\hline 3 & 21 & $6.35[4.78 ; 8.13]$ & 95.20 & $<0.001$ & 0.06 & 0.15 & \\
\hline 4 & 18 & $5.25[4.31 ; 6.27]$ & 85.00 & $<0.001$ & 0.03 & 0.12 & \\
\hline 5 & 20 & $7.44[4.59 ; 10.90]$ & 98.20 & $<0.001$ & 0.47 & 0.01 & \\
\hline 6 & 9 & $4.48[2.96 ; 6.29]$ & 93.20 & $<0.001$ & NA & NA & \\
\hline \multicolumn{8}{|l|}{ Sample size } \\
\hline$<500$ & 10 & $7.97[5.75 ; 10.51]$ & 84.00 & $<0.001$ & 0.50 & 0.53 & \multirow{6}{*}{$<0.001$} \\
\hline $500-1000$ & 16 & $8.43[6.83 ; 10.18]$ & 90.90 & $<0.001$ & 0.59 & 0.72 & \\
\hline $1000-1500$ & 16 & $8.25[6.43 ; 10.27]$ & 95.80 & $<0.001$ & 0.15 & 0.22 & \\
\hline $1500-3000$ & 6 & $6.01[3.84 ; 8.63]$ & 97.20 & $<0.001$ & NA & NA & \\
\hline $3000-10,000$ & 6 & $4.53[2.81 ; 6.63]$ & 98.40 & $<0.001$ & NA & NA & \\
\hline $10,000-$ & 4 & $3.13[2.32 ; 4.06]$ & 98.10 & $<0.001$ & NA & NA & \\
\hline \multicolumn{8}{|l|}{ Sampling method } \\
\hline cluster sampling & 5 & $5.55[3.13 ; 8.60]$ & 98.10 & $<0.001$ & NA & NA & \\
\hline random sampling & 37 & $7.66[6.60 ; 8.80]$ & 97.20 & $<0.001$ & $<0.001$ & 0.80 & 0.25 \\
\hline stratified sampling & 16 & $6.43[4.84 ; 8.21]$ & 97.80 & $<0.001$ & $<0.05$ & 0.05 & \\
\hline Sub-deficits & & & & & & & \\
\hline accuracy & 8 & $5.43[3.91 ; 7.18]$ & 97.80 & $<0.001$ & NA & NA & \\
\hline accuracy or comprehension & 4 & $7.60[5.46 ; 10.06]$ & 88.00 & $<0.001$ & NA & NA & \\
\hline accuracy or fluency & 5 & $9.71[4.29 ; 16.99]$ & 98.80 & $<0.001$ & NA & NA & \\
\hline comprehension & 8 & $7.97[4.60 ; 12.15]$ & 98.30 & $<0.001$ & NA & NA & 0.50 \\
\hline fluency & 6 & $6.64[4.34 ; 9.37]$ & 92.40 & $<0.001$ & NA & NA & \\
\hline Unclassified & 27 & $6.97[5.77 ; 8.27]$ & 97.30 & $<0.001$ & $<0.001$ & 0.44 & \\
\hline WHO region & & & & & & & \\
\hline Americas & 6 & $8.11[4.97 ; 11.93]$ & 98.80 & $<0.001$ & NA & NA & \\
\hline Eastern Mediterranean & 4 & $6.88[3.50 ; 11.27]$ & 95.90 & $<0.001$ & NA & NA & \\
\hline Europe & 11 & $6.55[4.49 ; 8.97]$ & 98.20 & $<0.001$ & $<0.05$ & 0.31 & 0.97 \\
\hline South-East Asia and Africa & 4 & $7.11[3.04 ; 12.66]$ & 97.50 & $<0.001$ & NA & NA & \\
\hline Western Pacific & 33 & $7.16[6.01 ; 8.41]$ & 97.30 & $<0.001$ & $<0.001$ & 0.44 & \\
\hline WB region & & & & & & & \\
\hline HIC & 18 & $7.09[5.54 ; 8.82]$ & 98.40 & $<0.001$ & $<0.01$ & 0.43 & \\
\hline MIC & 40 & $7.11[6.08 ; 8.20]$ & 97.00 & $<0.001$ & $<0.001$ & 0.07 & 0.97 \\
\hline
\end{tabular}

Abbreviations: WHO, World Health Organization; WB, World Bank; HIC, high-income countries; MIC, middleincome countries; NA, not applicable.

Unexpectedly, the prevalence of DD did not differ significantly when it was stratified according to writing system (alphabetic scripts: 7.26\%, 95\% CI, 5.94-8.71\%; logographic scripts: $6.97 \%, 95 \%$ CI, 5.86-8.16\%; $p>0.05$ ), or orthographic depth (shallow: $7.13 \%, 95 \%$ CI, 5.23-9.30\%; deep: $7.55 \%, 95 \%$ CI, $4.66-11.04 \%$; $p>0.05$ ), or grade (grade 1: $7.59 \%$, 95\% CI, 2.65-14.72\%; grade 2: $4.88 \%$, $95 \%$ CI, $2.94-7.28 \%$; grade $3: 6.35 \%, 95 \% \mathrm{CI}, 4.78-8.13 \%$; grade 4: $5.25 \%, 95 \%$ CI, $4.31-6.27 \%$; grade 5: $7.44 \%$, $95 \%$ CI, $4.59-10.90 \%$; grade 6: $4.48 \%$, $95 \%$ CI, $2.96-6.29 \% ; p>0.05)$. Similarly, there was no difference in the prevalence of DD among different subgroups of sub-deficits, sampling methods, WHO regions, and WB regions $(p>0.05)$. 


\begin{tabular}{|c|c|c|}
\hline Study & Events & Total \\
\hline Bruininks et al., 1971 & 287 & 2486 \\
\hline Berger et al., 1975 & 209 & 2802 \\
\hline Nathlie A. Badian, 1984 & 22 & 550 \\
\hline Lindgren et al., 1985 (study1) & 38 & 448 \\
\hline Lindgren et al., 1985 (study2) & 106 & 895 \\
\hline Farrag et al., 1988 & 84 & 2878 \\
\hline T?nnessen et al., 1993 & 75 & 734 \\
\hline Lewis et al., 1994 & 42 & 1056 \\
\hline Prior et al., 1995 & 195 & 1219 \\
\hline Zhang et al., 1996 & 44 & 967 \\
\hline Miles et al., 1998 & 269 & 11804 \\
\hline Nathlie A. Badian, 1999 & 162 & 5617 \\
\hline Flannery et al., 2000 & 1410 & 32223 \\
\hline Lv et al., 2000 & 65 & 688 \\
\hline Bhakta et al., 2002 & 98 & 1192 \\
\hline Yao et al., 2003 & 118 & 1151 \\
\hline Han Juan, 2005 & 65 & 800 \\
\hline Pan et al., 2006 & 50 & 332 \\
\hline Song Ranran, 2006 & 69 & 1096 \\
\hline Yu Yizhen, 2006 & 90 & 903 \\
\hline Chan et al., 2007 & 67 & 690 \\
\hline Lu Shan, 2007 & 55 & 820 \\
\hline Fluss et al., 2008 & 130 & 1020 \\
\hline Wang Zhong, 2008 & 407 & 3934 \\
\hline Zou Yuliang, 2008 & 25 & 255 \\
\hline Shaheen, H. A., 2010 & 22 & 206 \\
\hline Zou et al., 2010 & 23 & 587 \\
\hline Daseking et al., 2011 & 11 & 372 \\
\hline Jiménez et al., 2011(study1) & 164 & 1048 \\
\hline Jiménez et al., 2011(study2) & 110 & 557 \\
\hline Pouretemad et al., 2011 & 82 & 1562 \\
\hline Vale et al., 2011 & 74 & 1360 \\
\hline Zhu Dongmei, 2011 & 74 & 1048 \\
\hline Mogasale et al., 2012 & 121 & 1079 \\
\hline Luo Yan, 2012 & 33 & 435 \\
\hline Zhao Xiaochen, 2013 & 49 & 1069 \\
\hline Zuo et al., 2013 & 82 & 1206 \\
\hline Liu et al., 2014 & 46 & 1397 \\
\hline Irene Jepkoech Cheruiyot, 2015 & 9 & 120 \\
\hline Liu et al., 2016 & 1200 & 34748 \\
\hline Padhy et al., 2016 & 108 & 3600 \\
\hline Sheikh et al., 2016 & 64 & 567 \\
\hline Song Yi, 2016 & 23 & 395 \\
\hline Zhang et al., 2016 & 207 & 3508 \\
\hline Zhao et al., 2016 & 129 & 2348 \\
\hline Cuadro et al., 2017 & 75 & 1408 \\
\hline Qian Lizhu, 2017 & 38 & 325 \\
\hline Wang Rui, 2017 & 66 & 847 \\
\hline Yan Nairui, 2018 & 139 & 1179 \\
\hline Yoo et al., 2018 & 37 & 659 \\
\hline Zhou et al., 2018 & 15 & 369 \\
\hline Barbiero et al., 2019 & 350 & 9964 \\
\hline Fan et al., 2019 & 62 & 834 \\
\hline Gu et al. 2019 & 302 & 11668 \\
\hline Zhu et al., 2019 & 119 & 3673 \\
\hline Cai et al., 2020 & 81 & 1661 \\
\hline Su et al., 2020 & 62 & 624 \\
\hline YILIZHATI et al., 2020 & 119 & 1233 \\
\hline \multirow{2}{*}{\multicolumn{2}{|c|}{$\begin{array}{l}\text { Random effects model } \\
\text { Heterogeneity: } I^{2}=98 \%, \tau^{2}=0.0038, p=0\end{array}$}} & 168216 \\
\hline & & \\
\hline
\end{tabular}

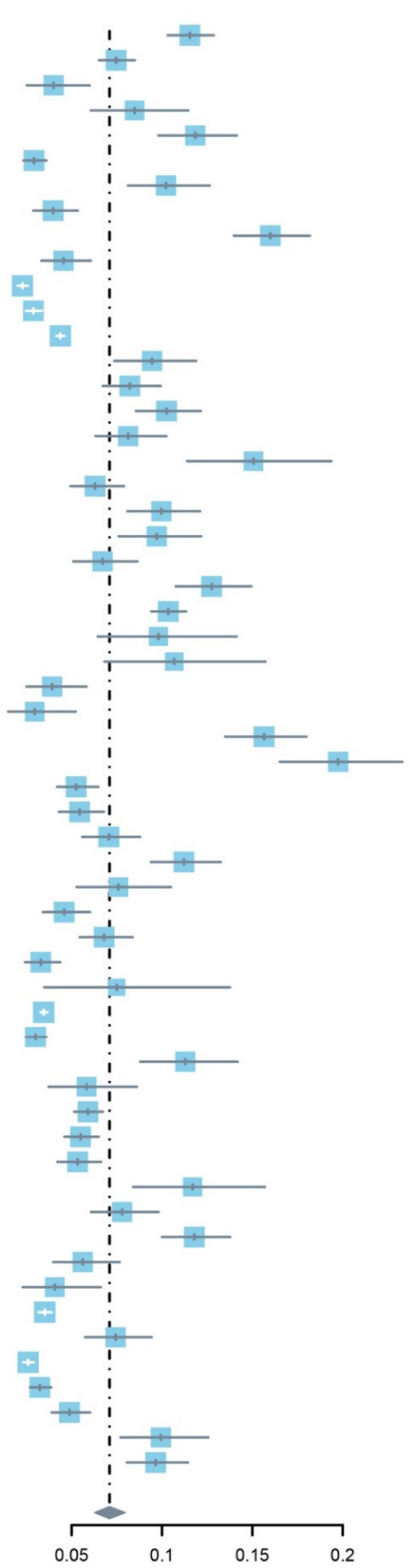

Proportion $\quad 95 \%-\mathrm{Cl}$ Weight

$0.12 \quad[0.10 ; 0.13] \quad 1.8 \%$

$0.07 \quad[0.07 ; 0.08] \quad 1.8 \%$

$0.04 \quad[0.03 ; 0.06] \quad 1.7 \%$

$0.08 \quad[0.06 ; 0.11] \quad 1.6 \%$

$0.12 \quad[0.10 ; 0.14] \quad 1.7 \%$

$0.03 \quad[0.02 ; 0.04] \quad 1.8 \%$

$0.10 \quad[0.08 ; 0.13] \quad 1.7 \%$

$0.04 \quad[0.03 ; 0.05]-1.8 \%$

$0.16 \quad[0.14 ; 0.18] \quad 1.8 \%$

$0.05 \quad[0.03 ; 0.06] \quad 1.7 \%$

$0.02 \quad[0.02 ; 0.03] \quad 1.9 \%$

$0.03 \quad[0.02 ; 0.03] \quad 1.8 \%$

$0.04 \quad[0.04 ; 0.05] \quad 1.9 \%$

$0.09 \quad[0.07 ; 0.12] \quad 1.7 \%$

$0.08 \quad[0.07 ; 0.10] \quad 1.8 \%$

$0.10 \quad[0.09 ; 0.12] \quad 1.8 \%$

$0.08 \quad[0.06 ; 0.10] \quad 1.7 \%$

$0.15 \quad[0.11 ; 0.19] \quad 1.6 \%$

$0.06 \quad[0.05 ; 0.08] \quad 1.8 \%$

$0.10 \quad[0.08 ; 0.12] \quad 1.7 \%$

$0.10 \quad[0.08 ; 0.12] \quad 1.7 \%$

$0.07 \quad[0.05 ; 0.09] \quad 1.7 \%$

$0.13 \quad[0.11 ; 0.15] \quad 1.8 \%$

$0.10 \quad[0.09 ; 0.11] \quad 1.8 \%$

$0.10 \quad[0.06 ; 0.14] \quad 1.5 \%$

$0.11 \quad[0.07 ; 0.16] \quad 1.4 \%$

$0.04 \quad[0.02 ; 0.06] \quad 1.7 \%$

$0.03 \quad[0.01 ; 0.05] \quad 1.6 \%$

$0.16 \quad[0.14 ; 0.18] \quad 1.8 \%$

$0.20 \quad[0.17 ; 0.23] \quad 1.7 \%$

$0.05 \quad[0.04 ; 0.06] \quad 1.8 \%$

$0.05 \quad[0.04 ; 0.07] \quad 1.8 \%$

$0.07 \quad[0.06 ; 0.09] \quad 1.8 \%$

$0.11 \quad[0.09 ; 0.13] \quad 1.8 \%$

$0.08 \quad[0.05 ; 0.10] \quad 1.6 \%$

$0.05 \quad[0.03 ; 0.06] \quad 1.8 \%$

$0.07 \quad[0.05 ; 0.08] \quad 1.8 \%$

$0.03 \quad[0.02 ; 0.04] \quad 1.8 \%$

$0.07 \quad[0.03 ; 0.14] \quad 1.2 \%$

$0.03 \quad[0.03 ; 0.04] \quad 1.9 \%$

$0.03 \quad[0.02 ; 0.04] \quad 1.8 \%$

$0.11 \quad[0.09 ; 0.14] \quad 1.7 \%$

$0.06 \quad[0.04 ; 0.09] \quad 1.6 \%$

$0.06 \quad[0.05 ; 0.07] \quad 1.8 \%$

$0.05 \quad[0.05 ; 0.06] \quad 1.8 \%$

$0.05 \quad[0.04 ; 0.07] \quad 1.8 \%$

$0.12 \quad[0.08 ; 0.16] \quad 1.5 \%$

$0.08 \quad[0.06 ; 0.10] \quad 1.7 \%$

$0.12 \quad[0.10 ; 0.14] \quad 1.8 \%$

$0.06 \quad[0.04 ; 0.08] \quad 1.7 \%$

$0.04 \quad[0.02 ; 0.07] \quad 1.6 \%$

$0.04 \quad[0.03 ; 0.04] \quad 1.9 \%$

$0.07 \quad[0.06 ; 0.09] \quad 1.7 \%$

$0.03 \quad[0.02 ; 0.03] \quad 1.9 \%$

$0.03 \quad[0.03 ; 0.04] \quad 1.8 \%$

$0.05 \quad[0.04 ; 0.06] \quad 1.8 \%$

$0.10 \quad[0.08 ; 0.13] \quad 1.7 \%$

$0.10 \quad[0.08 ; 0.11] \quad 1.8 \%$

$0.07 \quad[0.06 ; 0.08] \quad 100.0 \%$

Figure 2. Forest plot for the prevalence of DD using random-effects meta-analysis. 


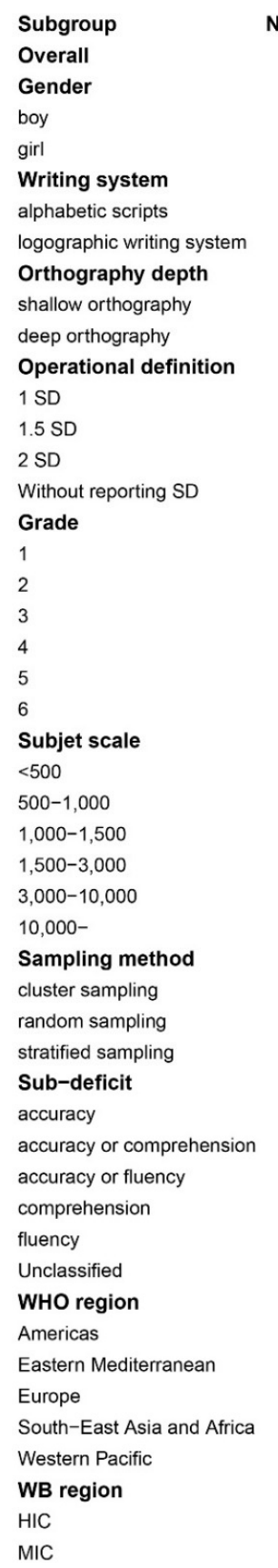

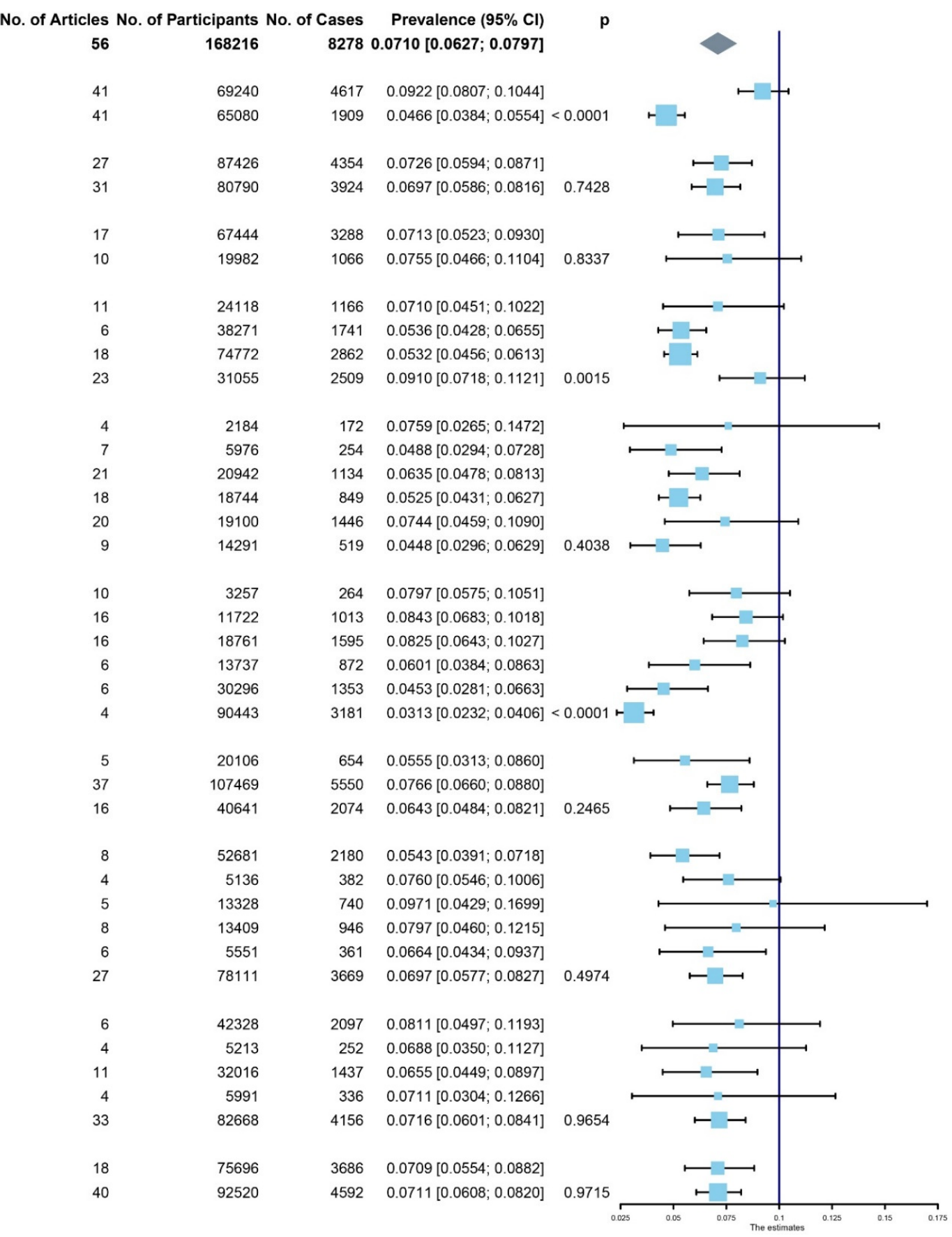

Figure 3. Forest plot for the subgroup meta-analysis of the prevalence of DD.

\section{Discussion}

This systematic review and meta-analysis estimated the worldwide prevalence of DD in primary school children, with a prevalence of $7.10 \%$ (95\% CI: $6.27-7.97 \%$ ). There was a significant gender difference, and the gender ratio of boys to girls was about 2:1. However, there was no language-specific difference in the prevalence of DD. In addition, the prevalence was influenced by operational definition and sample size, but not by subdeficits, grade, sampling method, WHO region or WB region. To our best knowledge, this is the first synthesized analysis on the prevalence of DD.

The pooled prevalence of $7.10 \%$ (95\% CI: $6.27-7.97 \%$ ) that is estimated in the present study is within the range of previous selective reviews, which have suggested that the prevalence of DD was in the range of $5-17.5 \%$ [14,15]. This is likely due to the similar diagnostic criteria of DD in most of the previous studies, in which DD was mainly defined 
as the low end of a normal distribution of word-reading ability [50]. Many disorders do not represent categories but instead the extremes on a continuous distribution that ranges from optimal outcomes to poor outcomes, with the underlying causal mechanisms being similar across the whole distribution. Essentially, most behaviorally defined disorders, including $\mathrm{DD}$, are continuous disorders. In the present study, we were able to pool the prevalence of DD in children based on the available evidence, which allowed our systematic review and meta-analysis to provide a more comprehensive estimate of the prevalence of DD.

Interestingly, our calculation of the gender ratio regarding DD of boys to girls is about 2:1 (boys: 9.22\%; 95\% CI: 8.07-10.44\%; girls: 4.66\%; 95\% CI: 3.84-5.54\%) ( $p<0.001$ ). This result is consistent with previous studies that reported a higher prevalence of DD for boys than for girls $[31,35,51]$. One explanation for this gender difference in DD prevalence is that some teachers are more likely to refer boys for assessment as having special problems because boys are often perceived as being more disruptive than girls [52]. However, focusing on large-scale epidemiological studies that were not based on school-referred samples, Rutter and his colleagues (2007) also found that boys were more likely than girls to have a reading disability, indicating that teacher bias cannot account entirely for gender difference [53]. A similar phenomenon is also found in logographic writing systems [54,55]. Other explanations come from biological and environmental hypotheses, including genetic causes [56,57], immunological factors, perinatal complications, differences in brain functioning due to differential exposure or sensitivity to androgens [58], and differential resilience to neural insult [59]. Our current study cannot provide enough evidence to support or reject any of the above hypotheses; therefore, more studies on DD in both boys and girls are needed in the future. At the same time, the current findings suggest that teachers may need to pay more attention to boys who exhibit reading difficulties or disorders.

Another important finding is that the prevalence of DD did not differ significantly when stratified by writing system (alphabetic scripts: $7.26 \%, 95 \%$ CI, 5.94-8.71\%; logographic scripts: $6.97 \%, 95 \%$ CI: $5.86-8.16 \% ; p=0.74)$. This is an unexpected result since logographic scripts are very distinctive (such as arbitrary mapping between the graphic and sound forms of words) relative to alphabetic scripts from the perspective of language; therefore, some experts believe that DD may be absent or rare in logographic scripts [26]. Research on DD has been initially and mainly conducted among the users of alphabetic scripts. Until the 1980s, researchers examined large samples of fifth-grade children in Japan, Taiwan, and the United States using a reading test and a battery of 10 cognitive tasks. However, the results showed that the prevalence of DD in Japan, Taiwan, and the United States was $5.4 \%, 7.5 \%$, and $6.3 \%$, respectively, suggesting that there is no significant difference in the prevalence of DD among different writing systems [27]. One explanation for this and our current findings is that the similarity in DD prevalence across different writing systems may be related to cross-cultural universality in the neurobiological and neurocognitive underpinnings of DD [15]. Some Western researchers and writers believed that Chinese characters are derived from pictographs, but this is not true. Instead, Chinese orthography is not primarily pictographic [27].

In addition, we found that DD prevalence did not differ across languages with different orthographic depths (shallow: 7.13\%, 95\% CI, 5.23-9.30\%; deep: 7.55\%, 95\% CI, 4.66-11.04\%; $p>0.05)$. These findings support the psycholinguistic grain size theory rather than the orthographic depth hypothesis $[28,29]$. When the orthography of the language is relatively shallow, readers can focus exclusively on the small psycholinguistic grain size of the phoneme. Otherwise, they will learn additional correspondences for larger orthographic units, such as syllables, rhymes, or whole words. Therefore, the prevalence of DD is very similar in both consistent and inconsistent orthographies, but its manifestations may vary according to orthographic depth.

Remarkably, operational definitions significantly affected the prevalence of DD. The present study found that studies with stricter operational definitions reported lower prevalence. Specifically, DD prevalence was significantly lower when using 1.5 SD and 2SD as 
the cut-off values than when not reporting SD (1.5 SD: 5.36\%, 95\% CI, 4.28-6.55\%; 2 SD: $5.32 \%, 95 \%$ CI, 4.56-6.13\%; without reporting SD: 9.10\%, 95\% CI, 7.18-11.21\%; both $p<0.05$, FDR-corrected). This finding is consistent with a recent selective review, suggesting that the prevalence depends on the severity of the reading problem-with lower rates for more severe problems [16]. Although the recognition of DD dates back over a century, no consensus has been reached regarding its diagnostic criteria. Therefore, many studies even use scores below 20\% [60], scores in the bottom 10\% [61], using different materials, and many other cut-offs for convenience. Essentially, all behaviorally defined disorders, including DD, are continuous disorders, and their operational definitions are found to be confusing in the current study. Perhaps now is not the time for change, with the continuous development of theoretical and empirical research; perhaps there will be a more appropriate operational definition for DD in the future.

It is worth noting that studies with more than 10,000 subjects reported a lower average prevalence of DD when compared to studies with 500-1000 and 1000-1500 subjects. By reviewing these studies, we found that the large sample-size studies have a common feature: that is, the diagnostic criteria were relatively strict. Only students who scored 1.5 or even 2 SD below the average on diagnostic tests were diagnosed as having DD [35,62,63]. Because of their strict diagnostic criteria, the prevalence was significantly lower than that of other subgroups $[18,20]$. Interestingly, in studies on other disorders, such as Tourette's syndrome, epidemiological investigations also demonstrated that studies with larger sample sizes tended to report a relatively lower prevalence [64,65], although the reason is not clear.

There was no grade difference in DD prevalence. In the literature, the association between grade and DD prevalence remains unclear. Some studies reported that DD prevalence was lower in higher grades than in lower grades [66], and explained this finding with the argument that DD symptoms improve through systematic learning [14]. Several studies, however, have shown a higher DD prevalence in higher grades, relative to that observed in lower grades [67]. In addition, most studies reported no difference in DD prevalence among different grades [68-70]. Studies have shown that the level of reading ability in the first few years of school will continue in the following years and that the DD prevalence during schooling does not change greatly [20,37]. Most previous studies only studied the prevalence of DD in specific grades, mainly in grades 3 to 5 , which makes it difficult to directly and empirically address the above issue $[55,70,71]$. In order to examine whether and how DD prevalence changes with progression through grades, future studies need to include all grades of elementary school and make the sample sufficiently representative. There was also no difference in the prevalence of sub-deficits. This shows that different tests and different indicators have no effect on the prevalence rate. That is, when there is a problem with accuracy, there is usually a problem with fluency or comprehension, and dyslexia shows no obvious differentiation.

As expected, we found significant heterogeneity when pooling the prevalence rates of DD. Thus, we performed sensitivity analyses, subgroup analyses, and meta-regression on many variables. After omitting each study one at a time (leave-1-out forest), the pooled prevalence of DD was shown to be robust and consistent. That is, no one study in this meta-analysis exerted a very high influence on our overall results. Under this condition, we further explored the patterns of effect sizes and heterogeneity in our data through a graphic display of heterogeneity (GOSH) plots [72] and found that all included studies had a low effect size and high heterogeneity (Figure A3). This result was consistent with the results of subgroup analysis, i.e., each subgroup had high heterogeneity (Table 1). In meta-regression, only the $p$-value of the sample size reached a significant level, which could explain the $39.56 \%$ heterogeneity $\left(\mathrm{R}^{2}=39.56 \%\right)$. This indicates that the large variations in sample size among different studies may be an important reason for their heterogeneity. Another reason for heterogeneity may be that children were drawn from studies performed in a wide variety of countries with differing cultural, ethnic, social, and economic characteristics. In conclusion, such high heterogeneity in epidemiological meta-analysis is not unexpected. However, the results of this study should be interpreted with caution. 
The strengths of this study include the comprehensive search strategies, a double review process, and stringent selection criteria. In our systematic review, we included only studies that were conducted in standard primary schools so that the generalizability of our results could be fully guaranteed. Moreover, we were able to pool the prevalence of DD in the included children based on the available evidence, which allowed our systematic review and meta-analysis to cover a broad scope regarding the prevalence of childhood DD.

Several intrinsic limitations of this study should also be acknowledged. First, the pooled prevalence of DD in the studied children might be affected by publication bias. We tried to minimize publication bias by searching for non-English literature and conference abstracts. Unfortunately, we could not completely rule out publication bias because of the observational nature of our study. Second, there were inherent disadvantages in pooling prevalence reports from disparate studies. For DD, sufficient data were available to pool the prevalence estimates. However, our subgroup analysis on the prevalence of any DD according to grade group, region group, and income group were only based on a limited number of studies that provided corresponding prevalence numbers. Third, ten variables across the included studies were systematically assessed, and only those studies with a large sample size were identified as showing a lower prevalence of DD. Previous studies [73,74] have suggested that socioeconomic factors were likely to contribute to disparities in DD prevalence rates in different subgroups. However, only high- and middle-income countries were assessed in the current study. Future studies are needed to explain the heterogeneity. More high-quality epidemiologic investigations on DD appear to be necessary, especially regarding different grades and in low-income countries.

\section{Conclusions}

This systematic review and meta-analysis is the first study to estimate the worldwide prevalence of DD. The results suggested that DD represents a considerable public health challenge worldwide (with a prevalence of 7.10\%,95\% CI: 6.27-7.97\%) and boys seem to be more affected than girls. There was no significant difference in the prevalence of DD either between logographic and alphabetic writing systems or between alphabetic scripts with different orthographic depths. However, a clear operational definition is urgently needed for the diagnosis of DD.

Author Contributions: L.Y. and J.Z. conceived and designed the protocol. L.Y. drafted the protocol manuscript. C.L., X.W. and J.Z. critically revised the manuscript for methodological and intellectual content. X.L., M.Z., Q.A. and Y.Z. participated in the development of the search strategy and data analysis. All authors have read and agreed to the published version of the manuscript.

Funding: The work was supported by the Key-Area Research and Development Program of Guangdong Province (grant number 2019B030335001), the Science and Technology Project of Guangzhou City (grant number 201804020085), the National Social Science Foundation of China (grant number 20\&ZD296), the National Science Foundation of China (grant number 32171063) and the Shanghai Clinical Research Center for Mental Health (grant number 19MC1911100).

Institutional Review Board Statement: Not applicable.

Informed Consent Statement: Not applicable.

Data Availability Statement: All data related to the research are presented in the article.

Conflicts of Interest: The authors declare no conflict of interest. 


\section{Appendix A}

Table A1. Search strategy.

\begin{tabular}{|c|c|}
\hline Database & Search Strategy \\
\hline $\begin{array}{l}\text { China National } \\
\text { Knowledge Infrastructure }\end{array}$ & 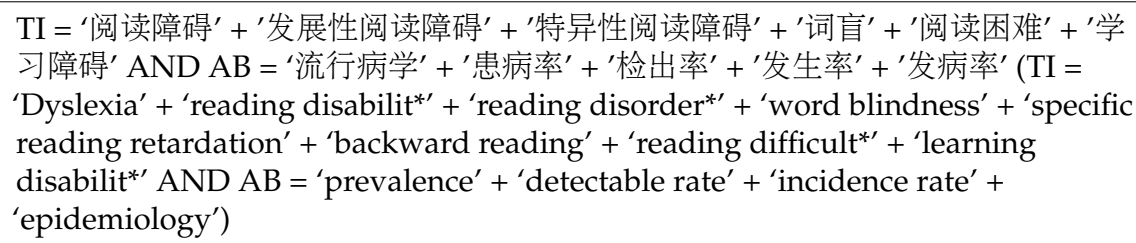 \\
\hline Wanfang & 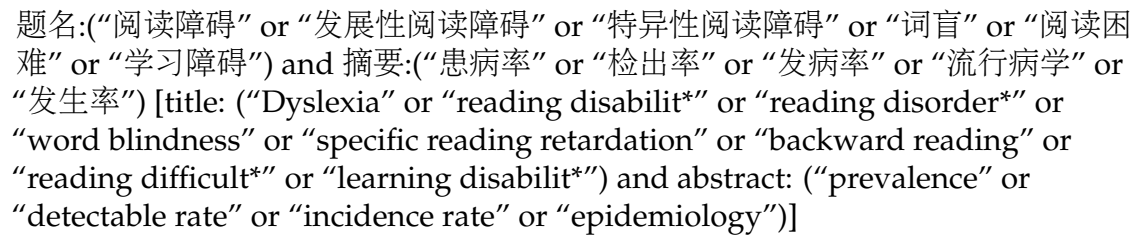 \\
\hline
\end{tabular}

$(R=$ 阅读障碍 $+R=$ 发展性阅读障碍 $+R=$ 特异性阅读障碍 $+R=$ 词盲 $+R=$ 阅读 困难 $+R=$ 学习障碍 $)$ AND $(U=$ 患病率 $+U=$ 检出率 $+U=$ 发病率 $+U=$ 流行病学

CQ-VIP $+\mathrm{U}=$ 发生率 $)\left[\left(\mathrm{R}=\right.\right.$ Dyslexia $+\mathrm{R}=$ reading disabilit ${ }^{*}+\mathrm{R}=$ reading disorder ${ }^{*}+\mathrm{R}=$ word blindness $+R=$ specific reading retardation $+R=$ backward reading $+R=$ reading difficult ${ }^{*}+\mathrm{R}=$ learning disabilit $\left.{ }^{*}\right)$ AND $(\mathrm{U}=$ prevalence $+\mathrm{U}=$ detectable rate $+\mathrm{U}=$ incidence rate $+\mathrm{U}=$ epidemiology)]

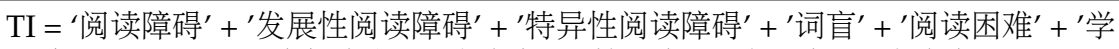
习障碍' AND TI = “流行病学' + '患病率' + '检出率' + '发生率' + '发病率' $(\mathrm{TI}=$

China Hospital

Knowledge Database

EBSCO Host

Proquest

PubMed

Web of Science

OATD database

Cochrane
'Dyslexia' + 'reading disabilit"' + 'reading disorder" + 'word blindness' + 'specific reading retardation' + 'backward reading' + 'reading difficult" + 'learning disabilit*' AND TI = 'prevalence' + 'detectable rate' + 'incidence rate' + 'epidemiology')

TI ((Dyslexia OR (reading disabilit*) OR (reading disorder*) OR (word blindness) OR (specific reading retardation) OR (backward reading) OR (reading difficult*) OR (learning disabilit*)) AND AB ((prevalence OR (detectable rate) OR (incidence rate) OR epidemiology))

((dyslexia) [SU] OR (reading disabilit*) [SU] OR (reading disorder*) [SU] OR (word blindness) [SU] OR (specific reading retardation) [SU] OR (backward reading) [SU] OR (reading difficult ${ }^{*}$ ) [SU] OR (learning disabilit*) [SU]) AND ((prevalence) [FT $\left.{ }^{\circ}\right]$ OR (detectable rate) $\left[\mathrm{FT}^{\circ}\right]$ OR (incidence rate) $\left[\mathrm{FT}^{\circ}\right] \mathrm{OR}$ (epidemiology) $\left[\mathrm{FT}^{\circ}\right]$ )

("dyslexia" [Title] OR "reading disabilit*" [Title] OR "reading disorder*" [Title] OR "word blindness" [Title] OR "specific reading retardation" [Title] OR "backward reading" [Title] OR "reading difficult*" [Title] OR "learning disabilit" [Title]) AND ("prevalence" [Title/Abstract] OR "detectable rate" [Title/Abstract] OR "incidence rate" [Title/Abstract] OR "epidemiology" [Title/Abstract])

$\mathrm{TI}=($ Dyslexia OR (reading disabilit*) OR (reading disorder*) OR (word blindness) OR (specific reading retardation) OR (backward reading) OR (reading difficult*) OR (learning disabilit*)) AND AB = (prevalence OR (detectable rate) OR (incidence rate) OR epidemiology)

abstract:(dyslexia OR "reading disabilit*" OR "reading disorder" OR "word blindness" OR "specific reading retardation" OR "backward reading" OR "reading difficult" ${ }^{*}$ OR "learning disabilit*" OR "reading difficult") AND (prevalence OR "detectable rate" OR "incidence rate" OR epidemiology)

('dyslexia' OR 'reading disabilit*' OR 'reading disorder*' OR 'word blindness' OR 'specific reading retardation' OR 'backward reading' OR 'reading difficult ${ }^{* \prime}$ OR 'learning disabilit*') in Title Abstract Keyword AND ('prevalence' OR 'detectable rate' OR 'incidence rate' OR 'epidemiology') in Abstract 
Table A1. Cont.

\begin{tabular}{|c|c|}
\hline Database & Search Strategy \\
\hline Springerlink & $\begin{array}{l}\text { TI("dyslexia" OR "reading disabilit*" OR "reading disorder*" OR "word } \\
\text { blindness" OR "specific reading retardation" OR "backward reading" OR "reading } \\
\text { difficult*" OR "learning disabilit*") AND AB("prevalence" OR "detectable rate" } \\
\text { OR "incidence rate" OR “epidemiology") }\end{array}$ \\
\hline EMBASE & $\begin{array}{l}\text { ((dyslexia OR 'reading disabilitt' OR 'reading disorder*' OR ‘word blindness' OR } \\
\text { 'specific reading retardation' OR 'backward reading' OR 'reading difficult }{ }^{* \prime} \text { OR } \\
\text { ‘learning disabilit*'):ti) AND ((prevalence OR 'detectable rate' OR 'incidence rate' } \\
\text { OR epidemiology):ab) }\end{array}$ \\
\hline
\end{tabular}

Table A2. Quality scores.

\begin{tabular}{|c|c|c|c|c|c|c|c|c|}
\hline \multirow[b]{2}{*}{ ID } & \multirow[b]{2}{*}{ Author } & \multirow{2}{*}{$\begin{array}{c}\text { Year } \\
\text { Published }\end{array}$} & \multicolumn{6}{|c|}{ Quality Score } \\
\hline & & & $\begin{array}{c}\text { Sample } \\
\text { Population }\end{array}$ & $\begin{array}{l}\text { Sample } \\
\text { Size }\end{array}$ & Participation & $\begin{array}{c}\text { Outcome } \\
\text { Assessment }\end{array}$ & $\begin{array}{l}\text { Analytical } \\
\text { Methods }\end{array}$ & Total Score \\
\hline 1 & Bruininks et al., 1971 & 1971 & 2 & 1 & 2 & 2 & 2 & 9 \\
\hline 2 & Berger et al., 1975 & 1975 & 2 & 1 & 2 & 2 & 2 & 9 \\
\hline 3 & Nathlie A. Badian, 1984 & 1984 & 1 & 0 & 2 & 2 & 2 & 7 \\
\hline 4 & Lindgren et al., 1985 & 1985 & 2 & 1 & 1 & 2 & 2 & 8 \\
\hline 5 & Farrag et al., 1988 & 1988 & 2 & 1 & 2 & 2 & 2 & 9 \\
\hline 6 & Tonnessen et al., 1993 & 1993 & 2 & 1 & 2 & 2 & 2 & 9 \\
\hline 7 & Lewis et al., 1994 & 1994 & 2 & 1 & 2 & 2 & 2 & 9 \\
\hline 8 & Prior et al., 1995 & 1995 & 2 & 1 & 2 & 2 & 2 & 9 \\
\hline 9 & Zhang et al., 1996 & 1996 & 2 & 1 & 2 & 2 & 2 & 9 \\
\hline 10 & Miles et al., 1998 & 1998 & 2 & 1 & 2 & 2 & 2 & 9 \\
\hline 11 & Nathlie A. Badian, 1999 & 1999 & 1 & 1 & 2 & 2 & 2 & 8 \\
\hline 12 & Lv et al., 2000 & 2000 & 1 & 0 & 2 & 1 & 2 & 6 \\
\hline 13 & Flannery et al., 2000 & 2000 & 2 & 1 & 2 & 2 & 2 & 9 \\
\hline 14 & Bhakta et al., 2002 & 2002 & 2 & 1 & 1 & 2 & 2 & 8 \\
\hline 15 & Yao et al., 2003 & 2003 & 2 & 0 & 2 & 1 & 2 & 7 \\
\hline 16 & Han Juan, 2005 & 2005 & 1 & 0 & 2 & 2 & 2 & 7 \\
\hline 17 & Pan et al., 2006 & 2006 & 1 & 0 & 2 & 1 & 2 & 6 \\
\hline 18 & Song Ranran, 2006 & 2006 & 2 & 0 & 2 & 1 & 2 & 7 \\
\hline 19 & Yu Yizhen, 2006 & 2006 & 1 & 0 & 2 & 1 & 2 & 6 \\
\hline 20 & Chan et al., 2007 & 2007 & 2 & 0 & 2 & 2 & 2 & 8 \\
\hline 21 & Lu Shan, 2007 & 2007 & 2 & 0 & 2 & 1 & 2 & 7 \\
\hline 22 & Fluss et al., 2008 & 2008 & 2 & 2 & 2 & 2 & 2 & 10 \\
\hline 23 & Wang Zhong, 2008 & 2008 & 2 & 0 & 2 & 1 & 2 & 7 \\
\hline 24 & Zou Yuliang, 2008 & 2008 & 2 & 0 & 2 & 1 & 2 & 7 \\
\hline 25 & Shaheen, H.A., 2010 & 2010 & 1 & 0 & 2 & 2 & 1 & 6 \\
\hline 26 & Zou et al., 2010 & 2010 & 1 & 0 & 2 & 1 & 2 & 6 \\
\hline 27 & Daseking et al., 2011 & 2011 & 1 & 0 & 2 & 2 & 1 & 6 \\
\hline 28 & Jiménez et al., 2011 & 2011 & 2 & 1 & 2 & 2 & 2 & 9 \\
\hline 29 & Pouretemad et al., 2011 & 2011 & 2 & 0 & 2 & 2 & 2 & 8 \\
\hline 30 & Vale et al., 2011 & 2011 & 2 & 1 & 2 & 2 & 2 & 9 \\
\hline 31 & Zhu Dongmei, 2011 & 2011 & 2 & 0 & 2 & 2 & 2 & 8 \\
\hline 32 & Mogasale et al., 2012 & 2011 & 2 & 1 & 2 & 2 & 2 & 9 \\
\hline 33 & Luo Yan, 2012 & 2012 & 1 & 0 & 2 & 1 & 2 & 6 \\
\hline 34 & Zhao Xiaochen, 2013 & 2013 & 1 & 0 & 2 & 2 & 2 & 7 \\
\hline 35 & Zuo et al., 2013 & 2013 & 1 & 0 & 2 & 1 & 2 & 6 \\
\hline 36 & Liu et al., 2014 & 2014 & 1 & 0 & 2 & 2 & 2 & 7 \\
\hline 37 & Irene Jepkoech Cheruiyot, 2015 & 2015 & 1 & 1 & 2 & 2 & 2 & 8 \\
\hline 38 & Liu et al., 2016 & 2016 & 1 & 0 & 2 & 1 & 2 & 6 \\
\hline 39 & Padhy et al., 2016 & 2016 & 2 & 2 & 2 & 1 & 1 & 8 \\
\hline 40 & Sheikh et al., 2016 & 2016 & 2 & 1 & 2 & 2 & 2 & 9 \\
\hline 41 & Song Yi, 2016 & 2016 & 2 & 0 & 2 & 1 & 2 & 7 \\
\hline 42 & Zhang et al., 2016 & 2016 & 2 & 0 & 2 & 1 & 2 & 7 \\
\hline 43 & Zhao et al., 2016 & 2016 & 1 & 0 & 2 & 1 & 2 & 6 \\
\hline 44 & Cuadro et al., 2017 & 2017 & 1 & 0 & 2 & 2 & 2 & 7 \\
\hline $\begin{array}{l}11 \\
45\end{array}$ & Qian Lizhu, 2017 & 2017 & 1 & 0 & 2 & 1 & 2 & 6 \\
\hline 46 & Wang Rui, 2017 & 2017 & 1 & 0 & 2 & 2 & 1 & 6 \\
\hline 47 & Yan Nairui, 2018 & 2018 & 1 & 0 & 2 & 1 & 2 & 6 \\
\hline 48 & Yoo et al., 2018 & 2018 & 1 & 0 & 2 & 2 & 2 & 7 \\
\hline 49 & Zhou et al., 2018 & 2018 & 1 & 0 & 2 & 1 & 2 & 6 \\
\hline 50 & Barbiero et al., 2019 & 2019 & 1 & 2 & 2 & 2 & 1 & 8 \\
\hline 51 & Fan et al., 2019 & 2019 & 1 & 0 & 2 & 2 & 1 & 6 \\
\hline 52 & Gu et al., 2019 & 2019 & 1 & 0 & 2 & 1 & 2 & 6 \\
\hline 53 & Zhu et al., 2019 & 2019 & 1 & 0 & 2 & 1 & 2 & 6 \\
\hline 54 & Cai et al., 2020 & 2020 & 1 & 2 & 2 & 2 & 2 & 9 \\
\hline 55 & Su et al., 2020 & 2020 & $\begin{array}{l}1 \\
1\end{array}$ & 0 & 2 & 1 & 2 & 6 \\
\hline 56 & Yilizhati Maimaiti et al. 2020 & 2020 & 1 & 0 & 2 & 2 & 2 & 7 \\
\hline
\end{tabular}


Table A3. Characteristics of included articles.

\begin{tabular}{|c|c|c|c|c|c|c|c|c|c|c|c|}
\hline ID & Author (Year) & Country & $\begin{array}{l}\text { Sampling } \\
\text { Strategy }\end{array}$ & Writng System & Ozone (WHO) & $\begin{array}{l}\text { Income } \\
\text { (WB) }\end{array}$ & Diagnostic Materials & Diagnostic Criteria & Sample Size & Prevalence Number & Prevalence Rate \\
\hline 1 & Bruininks et al., 1971 & USA & $\begin{array}{l}\text { random } \\
\text { sampling }\end{array}$ & alphabetic script & Americas & HIC & $\begin{array}{l}\text { (1) The Lorge-Thorndike intelligence } \\
\text { tetst; } \\
\text { (2) the reading comprehension and } \\
\text { arithmetic computation subtest of the } \\
\text { lowa Tests of Basic Skills }\end{array}$ & $\begin{array}{l}\text { (1) IQ } \geq 80 \text {; } \\
\text { (2) one grade or more below the } \\
\text { expected achievement in a reading test }\end{array}$ & $\begin{array}{l}\text { Total }=2486 \\
\text { boys } 12123 \\
\text { girls } 1253 \\
\text { 3rd }=1303 \\
6 \text { th }=1183\end{array}$ & $\begin{array}{l}\text { Total }=287 \\
\text { boys } 186 \\
\text { girls } 101 \\
\text { 3rd }=202 \\
\text { 6th }=85 \\
\end{array}$ & $\begin{array}{l}\text { Total }=11.54 \% \\
\text { boys }=15.00 \% \\
\text { girls }=8.06 \% \\
\text { 3rd }=15.50 \% \\
\text { 6th }=7.19 \%\end{array}$ \\
\hline 2 & Berger et al., 1975 & Great Britain & $\begin{array}{l}\text { random } \\
\text { sampling }\end{array}$ & alphabetic script & Europe & HIC & $\begin{array}{l}\text { (1) The NFER test NV5; } \\
\text { (2) the Watts-Vernon test SRI; } \\
\text { (3) the NFER test SRA } \\
\text { (4) the short form of the WISC; } \\
\text { (5) the Neale Analysis of Reading } \\
\text { Ability }\end{array}$ & $\begin{array}{l}\text { (1) SRA } \leq 15 \text { or } \mathrm{SRI} \leq 10 \text {; } \\
\text { (2) ) scores on either the accuracy or } \\
\text { comprehension scales on the Neale Test } \\
\text { fell } 30 \text { months or more below those } \\
\text { predicted }\end{array}$ & $\begin{array}{l}\text { Total }=2802 \\
\text { boys } 1428 \\
\text { girls }=1374\end{array}$ & $\begin{array}{l}\text { Total }=209 \\
\text { boys }=156 \\
\text { girls }=53\end{array}$ & $\begin{array}{l}\text { Total }=7.46 \% \\
\text { boys }=10.92 \% \\
\text { girls }=3.86 \%\end{array}$ \\
\hline 3 & Nathlie A. Badian, 1984 & USA & $\begin{array}{l}\text { random } \\
\text { sampling }\end{array}$ & alphabetic script & Americas & HIC & $\begin{array}{l}\text { (1) The Stanford achievement test, SAT; } \\
\text { (2) the Wechsler intelligence scale for } \\
\text { children-revised, WISC-R }\end{array}$ & $\begin{array}{l}\text { (1) Total reading score } \leq 20 \text { percentile } \\
\text { on SAT; } \\
\text { (2) } \mathrm{IQ} \geq 85\end{array}$ & $\begin{array}{l}\text { Total }=550 \\
\text { boys }=284 \\
\text { girls }=266\end{array}$ & $\begin{array}{l}\text { Total }=22 \\
\text { boys }=16 \\
\text { girls }=6\end{array}$ & $\begin{array}{l}\text { Total }=4.00 \% \\
\text { boys }=5.63 \% \\
\text { girls }=2.26 \%\end{array}$ \\
\hline 4 & $\begin{array}{l}\text { Lindgren et al, } 1985 \\
\text { (study1) }\end{array}$ & USA & cluster sampling & alphabetic script & Americas & HIC & $\begin{array}{l}\text { (1) The IEA reading test; } \\
\text { (2) the short form of the Wechsler } \\
\text { intelligence scale for children }\end{array}$ & $\begin{array}{l}\text { Reading score }<85 \text { and either VIQ or } \\
\text { PIQ } \geq 90\end{array}$ & Total $=895$ & Total $=106$ & Total $=11.84 \%$ \\
\hline 4 & $\begin{array}{l}\text { Lindgren et al, } 1985 \\
\text { (study2) }\end{array}$ & Italy & $\begin{array}{l}\text { stratified } \\
\text { sampling }\end{array}$ & alphabetic script & Europe & HIC & $\begin{array}{l}\text { (1) The IEA reading test; } \\
\text { (2) the short form of the Wechsler } \\
\text { intelligence scale for children }\end{array}$ & $\begin{array}{l}\text { Reading score }<85 \text { and either VIQ or } \\
\mathrm{PIQ} \geq 90\end{array}$ & Total $=448$ & Total $=38$ & Total $=8.48 \%$ \\
\hline 5 & Farrag et al., 1988 & Egypt & $\begin{array}{l}\text { stratified } \\
\text { sampling }\end{array}$ & alphabetic script & Eastern Mediterranean & MIC & $\begin{array}{l}\text { (1) The modified Alaska letters } \\
\text { identification tests (ALTT); } \\
\text { (2) the Assiut dyslexia screening test } \\
\text { (ADST) } \\
\text { (3) the Stanford-Binet IQ test }\end{array}$ & $\begin{array}{l}\text { Reading scores of less than } 142 \text { and IQ } \\
\text { levels of } 90 \text { or more. }\end{array}$ & $\begin{array}{l}\text { Total }=2878 \\
\text { boys } 1610 \\
\text { girls }=1268\end{array}$ & $\begin{array}{l}\text { Total }=84 \\
\text { boys }=57 \\
\text { girls }=27\end{array}$ & $\begin{array}{l}\text { Total }=2.92 \% \\
\text { boys }=3.54 \% \\
\text { girls }=2.13 \%\end{array}$ \\
\hline 6 & Tønnessen et al., 1993 & Norway & cluster sampling & alphabetic script & Europe & HIC & $\begin{array}{l}\text { (1) The silent word recognition test; } \\
\text { (2) the phonological decoding test }\end{array}$ & Scored below $20 \%$ on two tests & $\begin{array}{l}\text { Total }=734 \\
\text { boys }=394 \\
\text { girls }=340\end{array}$ & $\begin{array}{l}\text { Total }=75 \\
\text { boys }=50 \\
\text { girls }=25\end{array}$ & $\begin{array}{l}\text { Total }=10.22 \% \\
\text { boys }=12.69 \% \\
\text { girls }=7.35 \%\end{array}$ \\
\hline 8 & Prior et al., 1995 & Australia & $\begin{array}{l}\text { random } \\
\text { sampling }\end{array}$ & alphabetic script & Western Pacific & HIC & $\begin{array}{l}\text { (1) ACER word knowledge test; } \\
\text { (2) Rurrer child behavior scales } \mathrm{A} \text { and } \mathrm{B}\end{array}$ & $\begin{array}{l}\text { Scored more than } 1 \mathrm{SD} \text { below the } \\
\text { grade-2 mean on the reading test }\end{array}$ & Total $=1219$ & Total $=195$ & Total $=16.00 \%$ \\
\hline 9 & Zhang et al., 1996 & China & $\begin{array}{l}\text { stratified } \\
\text { sampling }\end{array}$ & $\begin{array}{l}\text { logographic } \\
\text { script }\end{array}$ & Western Pacific & MIC & $\begin{array}{l}\text { (1) A self-compiled reading } \\
\text { achievement inventory; } \\
\text { (2) combined Raven's test (city edition) }\end{array}$ & $\begin{array}{l}\text { Children's reading achievement was } \\
\text { more than } 2 S \mathrm{D} \text { below the average for } \\
\text { their grade }\end{array}$ & Total $=967$ & Total $=44$ & Total $=4.55 \%$ \\
\hline 10 & Miles et al., 1998 & Great Britain & cluster sampling & alphabetic script & Europe & HIC & $\begin{array}{l}\text { (1) The shortened Edinburgh reading } \\
\text { test; } \\
\text { (2) the Bangor dyslexia test (left-right, } \\
\text { months forward, and months reversed); } \\
\text { (3) the recall of digits subtest from the } \\
\text { British ability scales (BAS) }\end{array}$ & $\begin{array}{l}\text { (1) On the word recognition test, } \\
\text { outliers beyond } 1.5 \text { standard deviations } \\
\text { from the mean were excludedi } \\
\text { (2) those children whose residuals were } \\
\text { 2.0 SD were described as } \\
\text { "underachievers" }\end{array}$ & $\begin{array}{l}\text { Total }=11,804 \\
\text { boys }=5995 \\
\text { girls }=5809\end{array}$ & $\begin{array}{l}\text { Total }=269 \\
\text { boys }=223 \\
\text { girls }=46\end{array}$ & $\begin{array}{l}\text { Total }=2.28 \% \\
\text { boys }=3.72 \% \\
\text { girls }=0.79 \%\end{array}$ \\
\hline 11 & Nathlie A. Badian, 1999 & USA & cluster sampling & alphabetic script & Americas & HIC & $\begin{array}{l}\text { (1) The Wechsler preschool and primary } \\
\text { scale of intelligencec (WPPSII); } \\
\text { (2) the Stanford achievement test (SAT); } \\
\text { (3) the Wechlsler intelligencen s cale for } \\
\text { children-revised (WISC-R) }\end{array}$ & $\begin{array}{l}\text { (1) A reading comprehension score of } \\
\text { less than the } 25 \text { th percentile }(<90) \text { on } \\
\text { the SAT; } \\
\text { (2) scores were } 1.5 \text { SDs or more below } \\
\text { the expected level, based on listening } \\
\text { comprehension }\end{array}$ & $\begin{array}{l}\text { Total }=5617 \\
1 \text { st }=903 \\
2 \text { nd }=919 \\
\text { 3rd }=988 \\
4 \text { th }=896 \\
\text { thth }=908 \\
6 \text { th }=1003\end{array}$ & $\begin{array}{l}\text { Total }=162 \\
1 \text { st }=28 \\
\text { 2nd }=27 \\
\text { 3rd }=28 \\
\text { thth }=33 \\
\text { 5th }=32 \\
6 \text { th }=14\end{array}$ & $\begin{array}{l}\text { Total }=2.88 \% \\
1 \text { st }=3.10 \% \\
2 \text { nd }=2.94 \% \\
3 \text { rd }=2.83 \% \\
4 \text { th }=3.68 \% \\
5 \text { th }=3.52 \% \\
6 \text { th }=1.40 \%\end{array}$ \\
\hline
\end{tabular}


Table A3. Cont.

\begin{tabular}{|c|c|c|c|c|c|c|c|c|c|c|c|}
\hline ID & Author (Year) & Country & $\begin{array}{l}\text { Sampling } \\
\text { Strategy }\end{array}$ & Writng System & Ozone (WHO) & $\begin{array}{l}\text { Income } \\
\text { (WB) }\end{array}$ & Diagnostic Materials & Diagnostic Criteria & Sample Size & Prevalence Number & Prevalence Rate \\
\hline 12 & Flannery et al., 2000 & USA & $\begin{array}{l}\text { random } \\
\text { sampling }\end{array}$ & alphabetic script & Americas & HIC & $\begin{array}{l}\text { (1) The Weschler intelligence scale for } \\
\text { children (WISC); } \\
\text { (2) the wide range achievement test } \\
\text { (WRA) } \\
\text { (3) the NCPP behavioral checklist }\end{array}$ & $\begin{array}{l}\text { (1) IQ } \geq 80 \text { on WISC; } \\
\text { (2) reading scores }<1.5 \mathrm{SD} \text { on WRAT; } \\
\text { (3) in the firts or second grade at the } \\
\text { time of testing; } \\
\text { (4) English was the primary language; } \\
\text { (5) score was normal on the NCPP } \\
\text { behavioral checklist }\end{array}$ & $\begin{array}{l}\text { Total }=32,223 \\
\text { boys }=16,080 \\
\text { girls }=16,143\end{array}$ & $\begin{array}{l}\text { Total }=1410 \\
\text { boys }=947 \\
\text { girls }=463\end{array}$ & $\begin{array}{l}\text { Total }=4.38 \% \\
\text { boys }=5.89 \% \\
\text { girls }=2.87 \%\end{array}$ \\
\hline 13 & Lv et al., 2000 & China & $\begin{array}{l}\text { random } \\
\text { sampling }\end{array}$ & $\begin{array}{l}\text { logographic } \\
\text { script }\end{array}$ & Western Pacific & MIC & $\begin{array}{l}\text { (1) A self-compiled children's family } \\
\text { environment questionnaire; } \\
\text { (2) the Wechler intelligence scale for } \\
\text { children (WISC) }\end{array}$ & $\begin{array}{l}\text { (1) IQ > 70; } \\
\text { (2) 1 SD below the average score of their } \\
\text { peers in one or more subiects; } \\
\text { (3) qual learning opportunities with } \\
\text { other children; } \\
\text { (4) no nervous system diseases, visual, } \\
\text { auditory, or motor disorders }\end{array}$ & $\begin{array}{l}\text { Total }=688 \\
\text { boys }=357 \\
\text { girls }=331\end{array}$ & $\begin{array}{l}\text { Total }=65 \\
\text { boys }=44 \\
\text { girls }=21\end{array}$ & $\begin{array}{l}\text { Total }=9.45 \% \\
\text { boys }=12.32 \% \\
\text { girls }=6.34 \%\end{array}$ \\
\hline 15 & Yao et al., 2003 & China & $\begin{array}{l}\text { random } \\
\text { sampling }\end{array}$ & $\begin{array}{l}\text { loggographic } \\
\text { script }\end{array}$ & Western Pacific & MIC & $\begin{array}{l}\text { (1) The pupil rating scale-revised } \\
\text { screening for learning disabilities (PRS); } \\
\text { (2) Conners parent syymptom } \\
\text { questionnaire (PSS)); } \\
\text { (3) the YG personality sacle; } \\
\text { (4) a self-compiled questionaire on the } \\
\text { general conditions of parents and } \\
\text { children }\end{array}$ & $\begin{array}{l}\text { (1) A score of PRS }<60 \\
\text { (2) IQ }>08 \text {; } \\
\text { (3) No history of congenital diseases } \\
\text { and traumatic brain injury. }\end{array}$ & $\begin{array}{l}\text { Total }=1151 \\
\text { boys }=605 \\
\text { girls }=546\end{array}$ & $\begin{array}{l}\text { Total }=118 \\
\text { boys }=79 \\
\text { girls }=39\end{array}$ & $\begin{array}{l}\text { Total }=10.25 \% \\
\text { boys }=13.06 \% \\
\text { girls }=7.14 \%\end{array}$ \\
\hline 16 & Han Juan, 2005 & China & $\begin{array}{l}\text { random } \\
\text { sampling }\end{array}$ & $\begin{array}{l}\text { logographic } \\
\text { script }\end{array}$ & Western Pacific & MIC & 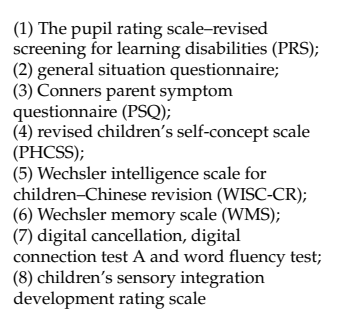 & $\begin{array}{l}\text { (1) A score of PRS } \leq 60 \text {; } \\
\text { (2) the average score of the main course } \\
\text { (Chinese, mathematics) was below the } \\
10 \text { percentile of the class, with LD } \\
\text { lasting more than one yearand it was } \\
\text { considered difficult to complete the } \\
\text { class and homework independently; } \\
\text { (3) the reading test score was less than } 1 \\
\text { SD of the mean of group test scores; } \\
\text { (4) IQ } \geq 85 \text {; } \\
\text { (5) no motivational problems, attention } \\
\text { deficit hyperactivity disorder, } \\
\text { emotional disorders and other } \\
\text { psychological problems, no organic } \\
\text { encephalopathy }\end{array}$ & Total $=800$ & Total $=65$ & Total $=8.13 \%$ \\
\hline 17 & Pan et al., 2006 & China & $\begin{array}{l}\text { random } \\
\text { sampling }\end{array}$ & $\begin{array}{l}\text { logographic } \\
\text { script }\end{array}$ & Western Pacific & MIC & $\begin{array}{l}\text { (1) IQ self-test; } \\
\text { (2) learning disability behavior scale; } \\
\text { (3) the learning motivation diagnostic } \\
\text { test (MAAT); } \\
\text { (4) (the enhanced learning factor } \\
\text { diagnostic test (FAT) }\end{array}$ & $\begin{array}{l}\text { (1) The IQ score was between } 85 \text { and } \\
\text { I40; } \\
\text { (2) there were one or more cases of I } \\
\text { value } \geq 24 \text {, II value } \geq 18, \text { III value } \geq 21 \text {, } \\
\text { IV value } \geq 9, \mathrm{~V} \text { value } \geq 18, \mathrm{VI} \text { value } \geq \\
\text { I2, VII value } \geq 12 \text { in the LD behavior } \\
\text { scale }\end{array}$ & $\begin{array}{l}\text { Total }=332 \\
\text { boys }=1199 \\
\text { girls }=161 \\
\text { 3rd }=164 \\
5 \text { th }=168\end{array}$ & $\begin{array}{l}\text { Total }=50 \\
\text { boys }=28 \\
\text { girls }=22 \\
\text { 3rd }=27 \\
\text { th }=23\end{array}$ & $\begin{array}{l}\text { Total }=15.06 \% \\
\text { boys }=16.57 \% \\
\text { girls }=13.66 \% \\
\text { 3rd }=16.46 \% \\
5 \text { th }=13.69 \%\end{array}$ \\
\hline
\end{tabular}


Table A3. Cont.

\begin{tabular}{|c|c|c|c|c|c|c|c|c|c|c|c|}
\hline ID & Author (Year) & Country & $\begin{array}{l}\text { Sampling } \\
\text { Strategy }\end{array}$ & Writng System & Ozone (WHO) & $\begin{array}{l}\text { Income } \\
\text { (WB) }\end{array}$ & Diagnostic Materials & Diagnostic Criteria & Sample Size & Prevalence Number & Prevalence Rate \\
\hline 18 & Song Ranran, 2006 & China & $\begin{array}{l}\text { random } \\
\text { sampling }\end{array}$ & $\begin{array}{l}\text { logographic } \\
\text { script }\end{array}$ & Western Pacific & MIC & $\begin{array}{l}\text { (1) A family situation questionnaire } \\
\text { compiled by the Shanghai Mental } \\
\text { Health Center; } \\
\text { (2) the pupil rating scale-revised } \\
\text { screening for learning disabilities (PRS); } \\
\text { (3) the dyslexia checklist for Chinese } \\
\text { (DCCC); } \\
\text { (4) the Wechsler intelligence scale for } \\
\text { children-Chinese revision (WISC-CR) }\end{array}$ & $\begin{array}{l}\text { (1) A score of PRS } \leq 60 ; \\
\text { (2) academic performance was in the } \\
\text { bottom } 10 \% \text {; } \\
\text { (3) the DCCC score was less than } 2 \mathrm{SD} \\
\text { of students in the same grade; } \\
\text { (4) an IV > } 80 \text { and no visual, auditory } \\
\text { impairment, no organic lesions }\end{array}$ & $\begin{array}{l}\text { Total }=1096 \\
\text { boys }=589 \\
\text { girls }=507 \\
\text { 3rd } 533 \\
\text { 4th }=370 \\
5 \text { th }=193\end{array}$ & $\begin{array}{l}\text { Total }=69 \\
\text { boys }=49 \\
\text { girls }=20 \\
\text { 3rd }=36 \\
\text { th }=22 \\
5 \text { th }=11\end{array}$ & $\begin{array}{l}\text { Total }=6.30 \% \\
\text { boys }=8.32 \% \\
\text { girls }=3.94 \% \\
\text { 3rd }=6.75 \% \\
\text { 4th }=5.95 \% \\
5 \text { th }=5.70 \%\end{array}$ \\
\hline 19 & Yu Yizhen, 2006 & China & $\begin{array}{l}\text { random } \\
\text { sampling }\end{array}$ & $\begin{array}{l}\text { logographic } \\
\text { script }\end{array}$ & Western Pacific & MIC & 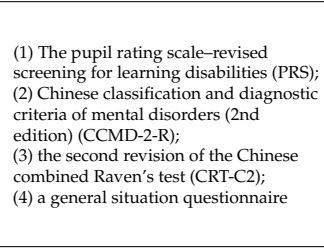 & 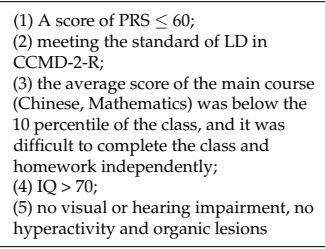 & $\begin{array}{l}\text { Total }=903 \\
\text { boys }=496 \\
\text { girls }=407\end{array}$ & $\begin{array}{l}\text { Total }=90 \\
\text { boys }=58 \\
\text { girls }=32\end{array}$ & $\begin{array}{l}\text { Total }=9.97 \% \\
\text { boys }=11.69 \% \\
\text { girls }=7.86 \%\end{array}$ \\
\hline 20 & Chan et al., 2007 & China & $\begin{array}{l}\text { stratified } \\
\text { random } \\
\text { sampling }\end{array}$ & $\begin{array}{l}\text { logographic } \\
\text { script }\end{array}$ & Western Pacific & HIC & $\begin{array}{l}\text { (1) The Hong Kong test of specific } \\
\text { learning difficulties in reading and } \\
\text { writing (HKT-SpLD) } \\
\text { (2) the Hon Kong Wechsler intelligence } \\
\text { scale for children (HK-WISC) }\end{array}$ & $\begin{array}{l}\text { (1) Scoring } 7 \text { or less on the literacy test } \\
\text { domain and on one or more of the } \\
\text { cognitive test domains; } \\
\text { (2) IQ } \geq 85\end{array}$ & $\begin{array}{l}\text { Total }=690 \\
\text { boys }=350 \\
\text { girls }=340\end{array}$ & $\begin{array}{l}\text { Total }=67 \\
\text { boys }=45 \\
\text { girls }=22\end{array}$ & $\begin{array}{l}\text { Total }=9.71 \% \\
\text { boys }=12.86 \% \\
\text { girls }=6.47 \%\end{array}$ \\
\hline 21 & Lu Shan, 2007 & China & $\begin{array}{l}\text { random } \\
\text { sampling }\end{array}$ & $\begin{array}{l}\text { logographic } \\
\text { script }\end{array}$ & Western Pacific & MIC & $\begin{array}{l}\text { (1) A general situation questionnaire; } \\
\text { (2) the pupil rating scale-revised } \\
\text { screening for learning disabibities (PRS); } \\
\text { (3) the second revision of the Chinese } \\
\text { combined Raven's test (CRT-Ch); } \\
\text { (4) the dyslexia checklist for Chinese } \\
\text { (DCCC) }\end{array}$ & $\begin{array}{l}\text { (1) A score of PRS < } 65 ; \\
\text { (2) the Chinese score lags behind the } \\
\text { average score of the same class by more } \\
\text { than } 1 \mathrm{SD} \text {, with LD lasting more than } \\
\text { one year, and it was difficult to } \\
\text { complete the class and homework } \\
\text { independently; } \\
\text { (3) the reading test score was less than } 2 \\
\text { SD of the mean of group test scores; } \\
\text { (4) IQ > 70; } \\
\text { (5) excluding other disabilities and } \\
\text { environmental factors }\end{array}$ & $\begin{array}{l}\text { Total }=820 \\
\text { boys }=427 \\
\text { girls }=393 \\
\text { 3rd }=332 \\
\text { thth }=2213 \\
5 \text { th }=275\end{array}$ & $\begin{array}{l}\text { Total }=55 \\
\text { boys }=43 \\
\text { girls }=12 \\
\text { 3rd }=23 \\
\text { th }=15 \\
5 \text { th }=17\end{array}$ & $\begin{array}{l}\text { Total }=6.70 \% \\
\text { boys }=10.07 \% \\
\text { girls }=3.05 \% \\
\text { 3rd }=6.93 \% \\
\text { 4th }=7.04 \% \\
5 \text { th }=6.18 \%\end{array}$ \\
\hline 22 & Fluss et al., 2008 & France & $\begin{array}{l}\text { stratified } \\
\text { sampling }\end{array}$ & alphabetic script & Europe & HIC & $\begin{array}{l}\text { (1) Reading comprehension; } \\
\text { (2) spelling skillili nonsledge } \\
\text { (3) mathematical knowledge }\end{array}$ & $\begin{array}{l}\text { On reading/spelling/mathematics (FL, } \\
\text { FO, FM, respectively), children' scores } \\
\text { were below } 1 \text { SD }\end{array}$ & $\begin{array}{l}\text { Total }=1020 \\
\text { boys }=544 \\
\text { girls }=476\end{array}$ & Total $=130$ & Total $=12.70 \%$ \\
\hline 23 & Wang Zhong, 2008 & China & $\begin{array}{l}\text { stratified } \\
\text { sampling }\end{array}$ & $\begin{array}{l}\text { logographic } \\
\text { script }\end{array}$ & Western Pacific & MIC & $\begin{array}{l}\text { (1) The pupil rating scale-revised } \\
\text { screening for learning disabilititis (PRS); } \\
\text { (2) the combined Raven's test (CRT) }\end{array}$ & $\begin{array}{l}\text { According to ICD-10, the total score of } \\
\text { PRS was less than } 60 \text {, or the score of } \\
\text { verbal type (factor A and B) was less } \\
\text { than 20, or the score of non-verbal type } \\
\text { (factor C, D and E) was less than } 40\end{array}$ & $\begin{array}{l}\text { Total }=3934 \\
\text { boys } 2321 \\
\text { girls }=1613 \\
\text { 1st }=601 \\
\text { 2nd }=617 \\
\text { 3rd }=668 \\
\text { th }=689 \\
\text { 5th }=669 \\
\text { 6th }=690\end{array}$ & $\begin{array}{l}\text { Total }=407 \\
\text { boys }=426 \\
\text { girls }=81 \\
\text { 1st }=87 \\
\text { 2nd }=63 \\
\text { 3rd }=69 \\
\text { th }=71 \\
\text { thth }=60 \\
\text { 6th }=57\end{array}$ & $\begin{array}{l}\text { Total }=10.35 \% \\
\text { boys }=14.05 \% \\
\text { girls }=5.02 \% \\
1 \text { st }=14.48 \% \\
\text { 2nd }=10.21 \% \\
\text { 3rd }=10.33 \% \\
\text { 4th }=10.30 \% \\
5 \text { th }=8.97 \% \\
\text { 6th }=8.26 \%\end{array}$ \\
\hline 24 & Zou Yuliang, 2008 & China & $\begin{array}{l}\text { random } \\
\text { sampling }\end{array}$ & $\begin{array}{l}\text { logographic } \\
\text { script }\end{array}$ & Western Pacific & MIC & $\begin{array}{l}\text { (1) The dyslexia checklist for Chinese } \\
\text { (DCCC); } \\
\text { (2) The second revision of the Chinese } \\
\text { combined Raver's test (CRT-C2); } \\
\text { (3) a students' family situation } \\
\text { questionnaire compiled by the research } \\
\text { group }\end{array}$ & $\begin{array}{l}\text { (1) T scores of each factor or the whole } \\
\text { score of DCCC scale were above } 98 \\
\text { percentile points; } \\
\text { (2) IQ }>80\end{array}$ & $\begin{array}{l}\text { Total }=255 \\
\text { boys }=123 \\
\text { girls }=132\end{array}$ & $\begin{array}{l}\text { Total }=25 \\
\text { boys }=19 \\
\text { girls }=6\end{array}$ & $\begin{array}{l}\text { Total }=9.80 \% \\
\text { boys }=15.45 \% \\
\text { girls }=4.55 \%\end{array}$ \\
\hline
\end{tabular}


Table A3. Cont.

\begin{tabular}{|c|c|c|c|c|c|c|c|c|c|c|c|}
\hline ID & Author (Year) & Country & $\begin{array}{l}\text { Sampling } \\
\text { Strategy }\end{array}$ & Writng System & Ozone (WHO) & $\begin{array}{l}\text { Income } \\
\text { (WB) }\end{array}$ & Diagnostic Materials & Diagnostic Criteria & Sample Size & Prevalence Number & Prevalence Rate \\
\hline 25 & Shaheen, H. A., 2010 & Egypt & $\begin{array}{l}\text { random } \\
\text { sampling }\end{array}$ & alphabetic script & Eastern Mediterranean & MIC & Arabic reading tests (ART) & $\begin{array}{l}\text { (1) With no visual, hearing problems, } \\
\text { motor impairment, mental retardation } \\
\text { (IQ less than 90\%) or major } \\
\text { psyychological disorder; } \\
\text { (2) scored } 40 \text { or less in ART }\end{array}$ & $\begin{array}{l}\text { Total }=206 \\
\text { boys }=117 \\
\text { girls }=89\end{array}$ & $\begin{array}{l}\text { Total }=22 \\
\text { boys }=12 \\
\text { girls }=10\end{array}$ & $\begin{array}{l}\text { Total }=10.68 \% \\
\text { boys }=10.26 \% \\
\text { girls }=11.24 \%\end{array}$ \\
\hline 28 & $\begin{array}{l}\text { Jiménez et al., } 2011 \text { (study } \\
\text { 1) }\end{array}$ & Spain & $\begin{array}{l}\text { random } \\
\text { sampling }\end{array}$ & alphabetic script & Europe & HIC & $\begin{array}{l}\text { (1) Culture-fair (or-free) intelligence } \\
\text { tests; } \\
\text { (2) reading comprehension test; } \\
\text { (3) fluency task; } \\
\text { (4) working memory test }\end{array}$ & 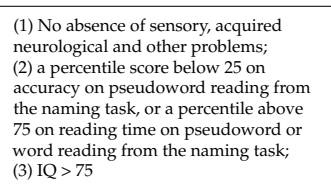 & $\begin{array}{l}\text { Total }=1048 \\
\text { boys }=630 \\
\text { girls }=418\end{array}$ & $\begin{array}{l}\text { Total }=164 \\
\text { boys }=98 \\
\text { girls }=66\end{array}$ & $\begin{array}{l}\text { Total }=15.65 \% \\
\text { boys }=15.56 \% \\
\text { girls }=15.79 \%\end{array}$ \\
\hline 28 & $\begin{array}{l}\text { Jiménez et al., } 2011 \text { (study } \\
\text { 2) }\end{array}$ & Guatemalan & $\begin{array}{l}\text { random } \\
\text { sampling }\end{array}$ & alphabetic script & Americas & MIC & $\begin{array}{l}\text { (1) Culture-fair (or -free) intelligence } \\
\text { tests; } \\
\text { (2) reading comprehension test; } \\
\text { (3) fluency task; } \\
\text { (4) working memory test }\end{array}$ & 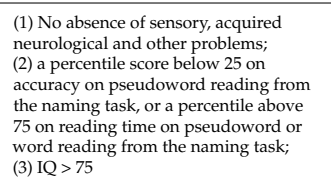 & $\begin{array}{l}\text { Total }=557 \\
\text { boys }=316 \\
\text { girls }=241\end{array}$ & $\begin{array}{l}\text { Total }=110 \\
\text { boys }=65 \\
\text { girls }=45\end{array}$ & $\begin{array}{l}\text { Total }=19.90 \% \\
\text { boys }=20.57 \% \\
\text { girls }=18.67 \%\end{array}$ \\
\hline 29 & Pouretemad et al., 2011 & Iran & $\begin{array}{l}\text { random } \\
\text { sampling }\end{array}$ & alphabetic script & Eastern Mediterranean & MIC & $\begin{array}{l}\text { (1) An analysis of Persian reading } \\
\text { ability (ARA); } \\
\text { (2) Whechsler intelligence scale for } \\
\text { children-third edition (WISC-III) }\end{array}$ & $\begin{array}{l}\text { (1) } \mathrm{IQ} \geq 85 \text {; } \\
\text { (2) reading scores in three trimesters of } \\
\text { one academic year were more than } 1.5 \\
\text { SD below that expected from their math } \\
\text { scores; } \\
\text { (3) no history of brain damage, hearing } \\
\text { or visual problems }\end{array}$ & $\begin{array}{l}\text { Total }=1562 \\
\text { boys }=773 \\
\text { girls }=789 \\
\text { list }=298 \\
\text { 2nd }=271 \\
\text { 3rd }=309 \\
\text { 4th }=330 \\
5 \text { th }=354\end{array}$ & $\begin{array}{l}\text { Total }=82 \\
\text { boys }=59 \\
\text { girls }=23 \\
\text { 1st }=11 \\
\text { 2nd }=9 \\
\text { 3rd }=22 \\
\text { 4ht }=20 \\
5 \text { th }=20\end{array}$ & $\begin{array}{l}\text { Total }=5.20 \% \\
\text { boys }=7.6 \% \% \\
\text { girls }=2.92 \% \\
\text { 1st }=3.96 \% \% \\
\text { 2nd }=3.32 \% \\
3 \text { drd }=7.12 \% \\
\text { 4ht }=6.0 .0 \% \\
\text { 5th }=5.65 \%\end{array}$ \\
\hline 30 & Vale et al., 2011 & Portugal & $\begin{array}{l}\text { random } \\
\text { sampling }\end{array}$ & alphabetic script & Europe & HIC & $\begin{array}{l}\text { (1) The TIL-reading age test; } \\
\text { (2) the PRP-word recognition test; } \\
\text { (3) the MPC Raven; } \\
\text { (4) the phonological awareness tests of } \\
\text { the ALEPE battery }\end{array}$ & 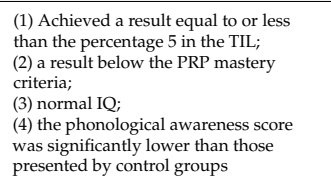 & $\begin{array}{l}\text { Total }=1360 \\
\text { 2nd }=443 \\
\text { 3rd }=445 \\
4 \text { th }=422\end{array}$ & $\begin{array}{l}\text { Total }=74 \\
\text { boys }=45 \\
\text { girls }=29 \\
\text { 2nd }=38 \\
\text { 3rd }=15 \\
4 \text { th }=21\end{array}$ & $\begin{array}{l}\text { Total }=5.44 \% \\
\text { 2nd }=7.70 \% \\
\text { 3rd }=3.37 \% \\
\text { 4th }=4.98 \%\end{array}$ \\
\hline 31 & Zhu Dongmei, 2011 & China & $\begin{array}{l}\text { random } \\
\text { sampling }\end{array}$ & $\begin{array}{l}\text { logographic } \\
\text { script }\end{array}$ & Western Pacific & MIC & 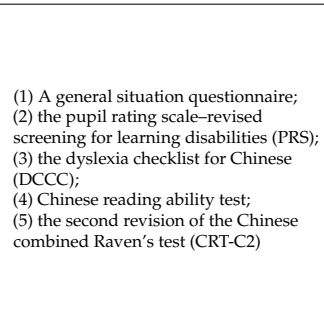 & 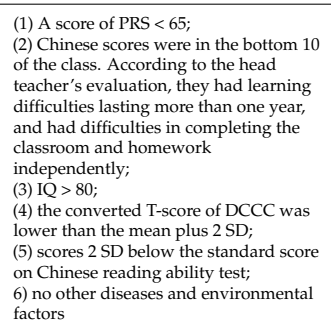 & $\begin{array}{l}\text { Total }=1048 \\
\text { boys }=513 \\
\text { girls }=535 \\
\text { 3rd }=425 \\
\text { 4th }=426 \\
5 \text { th }=197\end{array}$ & $\begin{array}{l}\text { Total }=74 \\
\text { Boy }=44 \\
\text { girls }=30 \\
\text { 3rd }=37 \\
\text { th }=20 \\
5 \text { th }=17\end{array}$ & $\begin{array}{l}\text { Total }=7.10 \% \\
\text { boys }=8.6 \% \\
\text { girls }=5.6 \% \\
\text { 3rd }=8.7 \% \\
\text { 4th }=4.7 \% \\
\text { 5th }=8.6 \%\end{array}$ \\
\hline
\end{tabular}


Table A3. Cont.

\begin{tabular}{|c|c|c|c|c|c|c|c|c|c|c|c|}
\hline ID & Author (Year) & Country & $\begin{array}{l}\text { Sampling } \\
\text { Strategy }\end{array}$ & Writng System & Ozone (WHO) & $\begin{array}{l}\text { Income } \\
\text { (WB) }\end{array}$ & Diagnostic Materials & Diagnostic Criteria & Sample Size & Prevalence Number & Prevalence Rate \\
\hline 32 & Mogasale et al., 2012 & India & $\begin{array}{l}\text { stratified } \\
\text { random } \\
\text { sampling }\end{array}$ & alphabetic script & South-East Asia & MIC & $\begin{array}{l}\text { (1) Rutter's proforma A; } \\
\text { (2) Seguin form board test; } \\
\text { (3) the specific learning disabilities } \\
\text { (SpLD) baattery test }\end{array}$ & $\begin{array}{l}\text { (1) Poor grades (Cor C+) of academic } \\
\text { record in two consecutive examinations; } \\
\text { (2) no visual, hearing idsorders or } \\
\text { severe physical condititions; } \\
\text { (3) IQ } \geq 90\end{array}$ & Total $=1079$ & Total $=121$ & Total $=11.21 \%$ \\
\hline 34 & Zhao Xiacchen, 2013 & China & $\begin{array}{l}\text { random } \\
\text { sampling }\end{array}$ & $\begin{array}{l}\text { logographic } \\
\text { script }\end{array}$ & Western Pacific & MIC & $\begin{array}{l}\text { (1) The Hong Kong behavior checklist } \\
\text { of specific learning difficulties in } \\
\text { reading and writing for primary school } \\
\text { students (second edition) (BCL-P(II)); } \\
\text { (2) Conners' teacher rating scale; } \\
\text { (3) Raven's test; } \\
\text { (4) the Hong Kong-specific learning } \\
\text { difficulties behavior checklist } \\
\text { (HKSLDC); } \\
\text { (5) the Hong Kong test of specific } \\
\text { learning difficultities in reading and } \\
\text { writing (HKT-SpLD) }\end{array}$ & $\begin{array}{l}\text { (1) The students in the bottom } 25 \% \text { of } \\
\text { each grade were selected according to } \\
\text { their most recent grade scores in } \\
\text { Chinese and math; } \\
\text { (2) the score on the BCL scale was } \\
\text { greater than or equal to 18; } \\
\text { (3) IQ } \geq 85 \text {; } \\
\text { (4) subjects performed } 1 \mathrm{SD} \text { lower than } \\
\text { the average level of the same grade in } \\
\text { one-minute word reading task, Chinese } \\
\text { word reading task, literacy task, and } \\
\text { fast naming task; } \\
\text { (5) no brain injury, emotional or } \\
\text { behavioral problems }\end{array}$ & Total $=1069$ & Total $=49$ & Total $=4.58 \%$ \\
\hline 36 & Liu et al., 2014 & China & $\begin{array}{l}\text { random } \\
\text { sampling }\end{array}$ & $\begin{array}{l}\text { logographic } \\
\text { script }\end{array}$ & Western Pacific & MIC & $\begin{array}{l}\text { (1) The one-minute Chinese word } \\
\text { reading test; } \\
\text { (2) Raven's standard progressive } \\
\text { matrices (SPM) }\end{array}$ & 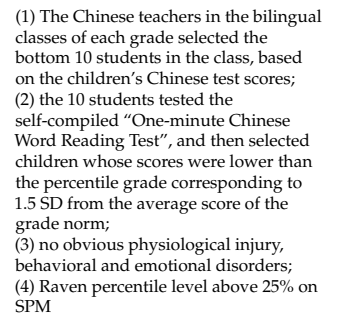 & $\begin{array}{l}\text { Total }=1397 \\
3 \text { rd }=458 \\
\text { 4th h } 418 \\
5 \text { th }=521\end{array}$ & $\begin{array}{l}\text { Total }=46 \\
3 \text { rd }=15 \\
4 \text { th }=11 \\
5 \text { th }=20\end{array}$ & $\begin{array}{l}\text { Total }=3.29 \% \\
3 \text { rd }=3.28 \% \\
4 \text { th }=2.63 \% \\
5 \text { th }=3.84 \%\end{array}$ \\
\hline 37 & $\begin{array}{l}\text { Irene Jepkoech Cheruiyot, } \\
2015\end{array}$ & The Republic of Kenya & $\begin{array}{l}\text { random } \\
\text { sampling }\end{array}$ & alphabetic script & Africa & MIC & $\begin{array}{l}\text { (1) The Burt reading test (1974) revised; } \\
\text { (2) the Pearson dyslexia screening test } \\
\text { for juniors (DSTT-J); } \\
\text { (3) a socio-demographic questionnaire }\end{array}$ & $\begin{array}{l}\text { (1) Reading age was way below } \\
\text { chronologicalage (by months or more) } \\
\text { on the Burt reading test (1974)-revised; } \\
\text { (2) an at-risk quotistient of } 0.6 \text { or greater } \\
\text { on the DST-J }\end{array}$ & $\begin{array}{l}\text { Total }=120 \\
\text { boys }=63 \\
\text { girls }=57\end{array}$ & $\begin{array}{l}\text { Total }=9 \\
\text { boys }=6 \\
\text { girls }=3\end{array}$ & $\begin{array}{l}\text { Total }=7.50 \% \\
\text { boys }=9.5 \% \% \\
\text { girls }=5.26 \%\end{array}$ \\
\hline 38 & Liu et al., 2016 & China & $\begin{array}{l}\text { random } \\
\text { sampling }\end{array}$ & $\begin{array}{l}\text { logographic } \\
\text { script }\end{array}$ & Western Pacific & MIC & $\begin{array}{l}\text { (1) The dyslexia checklist for Chinese } \\
\text { children (DCCC); } \\
\text { (2) the pupili rating scale-revised } \\
\text { screening for learning disabilities (PRS) }\end{array}$ & $\begin{array}{l}\text { (1) The score of DCCC was } 2 \mathrm{SD} \text { higher } \\
\text { than the mean score of all the students } \\
\text { in the same grade; } \\
\text { (2) a score of PRS } 65 \text {; } 65 \\
\text { (3) the Chinese language exam was } \\
\text { below the e } 10 \% \text { of all children in the } \\
\text { same grade; } \\
\text { (4) in intelectual disability, brain injury, } \\
\text { visual and auditory disorders, epilepsy, } \\
\text { or other neurological disorders. }\end{array}$ & $\begin{array}{l}\text { Total }=34,748 \\
\text { boys }=16,752 \\
\text { girls }=16,645 \\
\text { 3rd }=7901 \\
\text { 4ht }=8387 \\
5 \text { th }=8591 \\
6 \text { th }=8669\end{array}$ & $\begin{array}{l}\text { Total }=12000 \\
\text { boys }=893 \\
\text { girls }=301 \\
\text { 3rd }=316 \\
\text { 4th } 332 \\
5 \text { th }=3297 \\
\text { th }=255\end{array}$ & $\begin{array}{l}\text { Total }=3.45 \% \\
\text { boys }=5.0 .06 \% \\
\text { girls }=1.78 \% \\
\text { 3rd }=3.85 \% \\
\text { 4th }=3.81 \% \\
5 \text { th }=3.34 \% \\
6 \text { th }=2.86 \%\end{array}$ \\
\hline
\end{tabular}


Table A3. Cont.

\begin{tabular}{|c|c|c|c|c|c|c|c|c|c|c|c|}
\hline ID & Author (Year) & Country & $\begin{array}{l}\text { Sampling } \\
\text { Strategy }\end{array}$ & Writng System & Ozone (WHO) & $\begin{array}{l}\text { Income } \\
\text { (WB) }\end{array}$ & Diagnostic Materials & Diagnostic Criteria & Sample Size & Prevalence Number & Prevalence Rate \\
\hline 39 & Padhy et al., 2016 & India & $\begin{array}{l}\text { stratified } \\
\text { random } \\
\text { sampling }\end{array}$ & alphabetic script & South-East Asia & MIC & 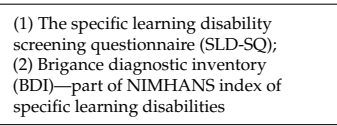 & $\begin{array}{l}\text { (1) Being considered by the teacher to } \\
\text { have some form of learning difficilty; } \\
\text { (2) scored above } 4 \text { on the SLD-SQ }\end{array}$ & Total $=3600$ & Total $=108$ & Total $=3.08 \%$ \\
\hline 41 & Song Yi, 2016 & China & $\begin{array}{l}\text { random } \\
\text { sampling }\end{array}$ & $\begin{array}{l}\text { logographic } \\
\text { script }\end{array}$ & Western Pacific & MIC & $\begin{array}{l}\text { (1) The pupil rating scale-revised } \\
\text { screening for learning disabilities (PRS); } \\
\text { (2) the second revision of the Chinese } \\
\text { combined Raven's test (CRT-CC); } \\
\text { (3) the dyslexia checklist for Chinese } \\
\text { (DCCC) }\end{array}$ & $\begin{array}{l}\text { (1) The Chinese score was ranked in the } \\
\text { bottom } 15 \% \text { of the grade } \\
\text { (2) the language part of the PRS scale } \\
\text { scored less than } 20 \text { points; } \\
\text { (3) normal IO; } \\
\text { (4) the transformed T-score of DCCC > } \\
70 ; \\
\text { (5) no visual, auditory and other } \\
\text { sensory disorders, no nervous system } \\
\text { diseases }\end{array}$ & $\begin{array}{l}\text { Total }=395 \\
\text { boys }=200 \\
\text { girls }=195\end{array}$ & $\begin{array}{l}\text { Total }=23 \\
\text { boys }=16 \\
\text { girls }=7\end{array}$ & $\begin{array}{l}\text { Total }=5.80 \% \\
\text { boys }=8.00 \% \\
\text { girls }=3.59 \%\end{array}$ \\
\hline 42 & Zhang et al., 2016 & China & $\begin{array}{l}\text { stratified } \\
\text { sampling }\end{array}$ & $\begin{array}{l}\text { logographic } \\
\text { script }\end{array}$ & Western Pacific & MIC & $\begin{array}{l}\text { (1) A family economic environment and } \\
\text { reading ability questionnaire; } \\
\text { (2) the dyslexia checklist for Uygur } \\
\text { children (DCUC); } \\
\text { (3) the Wechsler intelligence scale for } \\
\text { children-Chinese revision (WISC-CR) }\end{array}$ & $\begin{array}{l}\text { (1) The transformed T-scored of DCUC } \\
\text { >70; } \\
\text { (2) } \mathrm{Q}>80 \text {; } \\
\text { (3) no visual, auditory impairment, no } \\
\text { organic lesions }\end{array}$ & $\begin{array}{l}\text { Total }=3508 \\
\text { boys } 18837 \\
\text { girls }=1671 \\
3 \text { rd }=1281 \\
\text { 4th }=1210 \\
5 \text { th }=1017\end{array}$ & $\begin{array}{l}\text { Total }=207 \\
\text { boys }=144 \\
\text { girls }=63 \\
\text { 3rd }=85 \\
\text { 4th }=75 \\
5 \text { th }=47\end{array}$ & $\begin{array}{l}\text { Total }=5.90 \% \\
\text { boys }=7.84 \% \\
\text { girls }=3.78 \% \\
\text { 3rd }=6.63 \% \\
4 \text { th }=6.20 \% \\
5 \text { th }=4.62 \%\end{array}$ \\
\hline 43 & Zhao et al., 2016 & China & $\begin{array}{l}\text { stratified } \\
\text { sampling }\end{array}$ & $\begin{array}{l}\text { logographic } \\
\text { script }\end{array}$ & Western Pacific & MIC & $\begin{array}{l}\text { (1) The pupil rating scale-revised } \\
\text { screening for learning disabilities (PRS); } \\
\text { (2) the dyslexia checklist for Chinese } \\
\text { children (DCCC); } \\
\text { (3) the dyslexia checklist for Uyghur } \\
\text { children (DCUC); } \\
\text { (4) the home literacy environment - and } \\
\text { reading ability survey scale (HLEE-RA); } \\
\text { (5) the Chin-Wechsler intelligence } \\
\text { ccale for children (C-WISC) }\end{array}$ & $\begin{array}{l}\text { (1) A score of PRS < } 65 \text {; } \\
\text { (2) the score of DCCC was } 2 \text { SD higher } \\
\text { than the mean scores of Han Chinese } \\
\text { children; DCUC score was } 2 \mathrm{SD} \text { higher } \\
\text { than the mean scores of Uyghur } \\
\text { children; } \\
\text { (3) } \mathrm{Q}>\mathrm{80} \\
\text { (4) no visual and/or auditory disorders } \\
\text { or psychiatric diseases }\end{array}$ & $\begin{array}{l}\text { Total }=2348 \\
\text { boys }=11163 \\
\text { girls }=1185 \\
\text { 3rd }=623 \\
\text { 4th }=719 \\
5 \text { h h } 798 \\
6 \text { h }=208\end{array}$ & $\begin{array}{l}\text { Total }=129 \\
\text { boys }=86 \\
\text { girls }=43 \\
\text { 3rd }=39 \\
\text { 4th }=48 \\
\text { thth }=39 \\
\text { 6th }=3\end{array}$ & $\begin{array}{l}\text { Total }=5.49 \% \\
\text { boys }=7.3 \% \% \\
\text { girls }=3.36 \% \\
\text { 3rd }=6.26 \% \\
\text { thth }=6.66 \% \\
5 \text { th }=4.89 \% \\
\text { th }=1.44 \%\end{array}$ \\
\hline 44 & Cuadro et al., 2017 & Spain & $\begin{array}{l}\text { stratified } \\
\text { sampling }\end{array}$ & alphabetic script & Europe & HIC & $\begin{array}{l}\text { (1) Reading efficiency test; } \\
\text { (2) orthographic level test }\end{array}$ & $\begin{array}{l}\text { A cut-off point of } 1.5 \mathrm{SD} \text { below the } \\
\text { mean of each school year in the reading } \\
\text { efficiency test }\end{array}$ & $\begin{array}{l}\text { Total }=1408 \\
\text { boys }=718 \\
\text { girls }=690 \\
\text { 2nd }=308 \\
3 \text { rd }=305 \\
\text { 4th }=273 \\
\text { 5th }=271 \\
6 \text { th }=251\end{array}$ & $\begin{array}{l}\text { Total }=75 \\
\text { boys }=47 \\
\text { girls }=28 \\
\text { 2nd }=10 \\
\text { rrd }=12 \\
\text { th }=12 \\
5 \text { th }=22 \\
\text { th }=19\end{array}$ & $\begin{array}{l}\text { Total }=5.3 .2 \% \\
\text { boys }=6.55 \% \\
\text { girls }=4.06 \% \\
2 \text { nd }=3.20 \% \\
\text { 3rd }=3.90 \% \\
\text { 4th }=4.40 \% \\
5 \text { the }=8.10 \% \\
6 \text { th }=7.60 \%\end{array}$ \\
\hline 45 & Qian Lizhu, 2017 & China & $\begin{array}{l}\text { random } \\
\text { sampling }\end{array}$ & Chinese & Western Pacific & MIC & $\begin{array}{l}\text { The dyslexia checklist for Chinese } \\
\text { children (DCCC) }\end{array}$ & T score of any factor or full scale $\geq 70$ & $\begin{array}{l}\text { Total }=325 \\
\text { boys }=179 \\
\text { girls }=146 \\
5 \text { tht }=221 \\
6 \text { th }=104 \\
\end{array}$ & $\begin{array}{l}\text { Total }=38 \\
\text { boys }=29 \\
\text { girls }=9 \\
\text { 5hth }=26 \\
6 \text { th }=12 \\
\end{array}$ & $\begin{array}{l}\text { Total }=11.69 \% \\
\text { boys }=16.20 \% \\
\text { girls }=6.16 \% \\
5 \text { tht }=11.7 \% \% \\
6 \text { th }=11.54 \%\end{array}$ \\
\hline 46 & Wang Rui, 2017 & China & $\begin{array}{l}\text { random } \\
\text { sampling }\end{array}$ & $\begin{array}{l}\text { logographic } \\
\text { script }\end{array}$ & Western Pacific & MIC & $\begin{array}{l}\text { (1) Chinese character literacy test for } \\
\text { primary school students; } \\
\text { (2) the pupil rating scale-revised } \\
\text { screening for learning disabilities (PRS); } \\
\text { (3) Raven's standard progressive } \\
\text { matrices (SPM); } \\
\text { (4) the grade of Chinese }\end{array}$ & $\begin{array}{l}\text { (1) The literacy level was } 1.5 \mathrm{SD} \text { below } \\
\text { the grade average, according to the } \\
\text { Chinese character literacy test for } \\
\text { primary school students; } \\
\text { (2) a soore of PRS < } 65 \text {; } \\
\text { (3) normal IQ; } \\
\text { (4) The students' Chinese score was } \\
\text { lower than the grade average level in } \\
\text { the past half a year }\end{array}$ & Total $=847$ & Total $=66$ & Total $=7.79 \%$ \\
\hline
\end{tabular}


Table A3. Cont.

\begin{tabular}{|c|c|c|c|c|c|c|c|c|c|c|c|}
\hline ID & Author (Year) & Country & $\begin{array}{l}\text { Sampling } \\
\text { Strategy }\end{array}$ & Writng System & Ozone (WHO) & $\begin{array}{l}\text { Income } \\
\text { (WB) }\end{array}$ & Diagnostic Materials & Diagnostic Criteria & Sample Size & Prevalence Number & Prevalence Rate \\
\hline 47 & Yan Nairui, 2018 & China & $\begin{array}{l}\text { random } \\
\text { sampling }\end{array}$ & $\begin{array}{l}\text { logographic } \\
\text { script }\end{array}$ & Western Pacific & MIC & 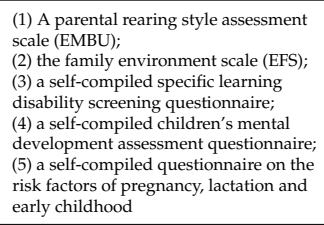 & $\begin{array}{l}\text { (1) The students in the bottom } 25 \% \text { of } \\
\text { each grade were selected according to } \\
\text { their most recent grade scores in } \\
\text { Chinese and math; } \\
\text { (2) a score of the specific learning } \\
\text { disability screening questionnaire } \geq 34\end{array}$ & $\begin{array}{l}\text { Total }=1179 \\
\text { boys }=642 \\
\text { girls }=537 \\
1 \text { st }=382 \\
3 \text { d }=465 \\
5 \text { th }=332\end{array}$ & $\begin{array}{l}\text { Total }=139 \\
\text { boys }=92 \\
\text { girls }=47 \\
1 \text { st }=46 \\
3 \text { d }=55 \\
5 \text { th }=38\end{array}$ & $\begin{array}{l}\text { Total }=11.79 \% \\
\text { boys }=14.33 \% \\
\text { girls }=8.75 \% \\
\text { 1st }=12.04 \% \\
\text { 5th }=11.45 \% \\
3 \text { rd }=11.83 \%\end{array}$ \\
\hline 48 & Yoo et al., 2018 & South Korea & $\begin{array}{l}\text { random } \\
\text { sampling }\end{array}$ & alphabetic script & Western Pacific & MIC & 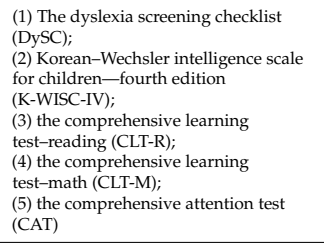 & $\begin{array}{l}\text { Being in the bottom } 15 \% \text { on DySC and } \\
\text { CLIT-R, and having no intelligence or } \\
\text { attention problems }\end{array}$ & $\begin{array}{l}\text { Total }=659 \\
\text { boys }=340 \\
\text { girls }=319\end{array}$ & $\begin{array}{l}\text { Total }=37 \\
\text { boys }=22 \\
\text { girls }=15\end{array}$ & $\begin{array}{l}\text { Total }=5.61 \% \\
\text { boys }=6.473 \% \\
\text { girls }=4.70 \%\end{array}$ \\
\hline 49 & Zhou et al., 2018 & China & $\begin{array}{l}\text { random } \\
\text { sampling }\end{array}$ & $\begin{array}{l}\text { logographic } \\
\text { script }\end{array}$ & Western Pacific & MIC & $\begin{array}{l}\text { (1) The dyslexia checklist for Chinese } \\
\text { (DCCC); } \\
\text { (2) the second revision of the Chinese } \\
\text { combined Raven's test (CRTTC2); } \\
\text { (3) the pupil rating scale-revised } \\
\text { screening for learning disabilities (PRS) }\end{array}$ & $\begin{array}{l}\text { (1) The transformed T-scored of DCCC } \\
\text { >70; } \\
\text { (2) the Chinese score ranked in the } \\
\text { bottom } 10 \text { of the class, with LD lasting } \\
\text { more than one yearand it was difficult } \\
\text { to complete the class and homework } \\
\text { independently; } \\
\text { (3) a score of PRS }>65 ; \\
\text { (4) IQ } \geq 80 ; \\
\text { (5) no visual, auditory and other } \\
\text { sensory disorders, no nervous system } \\
\text { diseases }\end{array}$ & $\begin{array}{l}\text { Total }=369 \\
\text { boys } 188 \\
\text { girls }=181\end{array}$ & $\begin{array}{l}\text { Total }=15 \\
\text { boys }=13 \\
\text { girls }=2\end{array}$ & $\begin{array}{l}\text { Total }=4.07 \% \\
\text { boys }=6.9 \% \\
\text { girls }=1.1 \%\end{array}$ \\
\hline 50 & Barbiero et al., 2019 & Italy & $\begin{array}{l}\text { random } \\
\text { sampling }\end{array}$ & alphabetic script & Europe & HIC & 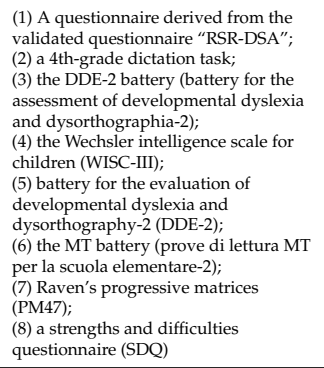 & 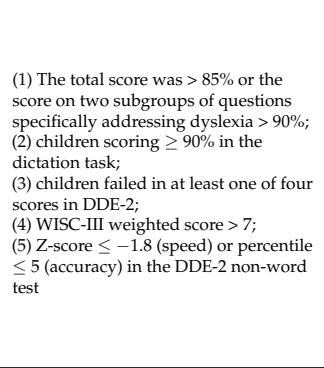 & Total $=9964$ & Total $=350$ & Total $=3.51 \%$ \\
\hline 51 & Fan et al., 2019 & China & $\begin{array}{l}\text { random } \\
\text { sampling }\end{array}$ & Chinese & Western Pacific & MIC & Multiple achievement tests (MATs) & 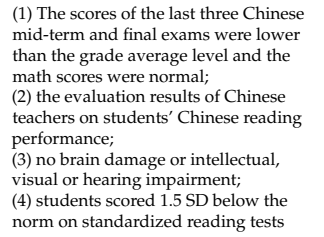 & $\begin{array}{l}\text { Total }=834 \\
\text { boys }=444 \\
\text { girls }=390\end{array}$ & $\begin{array}{l}\text { Total }=62 \\
44 \mathrm{th}=35 \\
5 \mathrm{th}=27\end{array}$ & Total $=7.43 \%$ \\
\hline
\end{tabular}


Table A3. Cont.

\begin{tabular}{|c|c|c|c|c|c|c|c|c|c|c|c|}
\hline ID & Author (Year) & Country & $\begin{array}{l}\text { Sampling } \\
\text { Strategy }\end{array}$ & Writng System & Ozone (WHO) & $\begin{array}{l}\text { Income } \\
\text { (WB) }\end{array}$ & Diagnostic Materials & Diagnostic Criteria & Sample Size & Prevalence Number & Prevalence Rate \\
\hline 52 & Gu et al. 2019 & China & $\begin{array}{l}\text { Stratified cluster } \\
\text { sampling }\end{array}$ & Chinese & Western Pacific & MIC & $\begin{array}{l}\text { (1) The dyslexia checklist for Chinese } \\
\text { children (DCCC); } \\
\text { (2) the pupili rating scale-revised } \\
\text { screening for learning disabilities (PRS); }\end{array}$ & $\begin{array}{l}\text { (1) No brain diseases such as visual and } \\
\text { hearing impairment, brain trauma, } \\
\text { epilepsy, etc.; } \\
\text { (2) the Chinese score was in the last 10\% } \\
\text { of the classs; } \\
\text { (3) one subscale or total score in the } \\
\text { DCCC was } 2 \text { SD higher than that of } \\
\text { children of the same age; } \\
\text { (4) the score of the PRS was < } 65\end{array}$ & $\begin{array}{l}\text { Total }=11,668 \\
\text { boys }=6829 \\
\text { girls }=5369 \\
2 \text { 2nd }=2916 \\
\text { 3rd }=273 \\
\text { 4th }=2254 \\
5 \text { th }=2537 \\
6 \text { h }=1218\end{array}$ & $\begin{array}{l}\text { Total }=302 \\
\text { boys }=233 \\
\text { girls }=69 \\
\text { 2nd }=79 \\
\text { 3rd }=66 \\
\text { th }=58 \\
\text { 5hth }=665 \\
6 \text { th }=33\end{array}$ & $\begin{array}{l}\text { Total }=2.5 \% \% \\
\text { boys }=3.7 \% \% \\
\text { girls }=1.29 \% \\
2 \text { nd }=2.71 \% \\
3 \text { d }=2.41 \% \\
\text { 4th }=2.5 \% \\
5 \text { th }=2.6 \% \% \\
6 \text { th }=2.71 \%\end{array}$ \\
\hline 53 & Zhu et al., 2019 & China & $\begin{array}{l}\text { Stratified cluster } \\
\text { sampling }\end{array}$ & Chinese & Western Pacific & MIC & $\begin{array}{l}\text { (1) The dyslexia checklist for Chinese } \\
\text { children (DCCC); } \\
\text { (2) the pupil rating scale-revised } \\
\text { screening for learning disabilities (PRS); }\end{array}$ & $\begin{array}{l}\text { (1) No brain diseases such as visual and } \\
\text { hearing impaiment, brain trauma, } \\
\text { epilepsy, etci; } \\
\text { (2) the Chinese score was in the last } 10 \% \\
\text { of the class; } \\
\text { (3) one subscale or total score in the } \\
\text { DCCC was } 2 \text { SD higher than that of } \\
\text { children of the same age; } \\
\text { (4) score of the PRS < } 655\end{array}$ & $\begin{array}{l}\text { Total }=3673 \\
\text { boys }=2118 \\
\text { girls }=1555 \\
\text { 3rdd }=838 \\
\text { 4the } 924 \\
5 \text { th }=946 \\
6 \text { th }=965\end{array}$ & $\begin{array}{l}\text { Total }=119 \\
\text { boys= } 95 \\
\text { girls }=24 \\
\text { 3rd }=13 \\
\text { the }=29 \\
5 \text { th }=36 \\
6 \text { th }=41\end{array}$ & 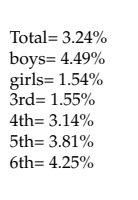 \\
\hline 54 & Cai et al., 2020 & China & $\begin{array}{l}\text { Stratified cluster } \\
\text { sampling }\end{array}$ & Chinese & Western Pacific & MIC & $\begin{array}{l}\text { (1) The pupil rating scale-revised } \\
\text { ccreening for learning disabilities (PRS); } \\
\text { (2) the Chinese character recognition } \\
\text { measure and assessment scale for } \\
\text { primary school children, } \\
\text { (3) a combined Raven's test }\end{array}$ & $\begin{array}{l}\text { (1) PRS score below 65; } \\
\text { (2) at least 1SD below the average level } \\
\text { of actual grade in Chinese character } \\
\text { recognition; } \\
\text { (3) IQ }>80 ; \\
\text { (4) } 8 \text { according to the head-teachers' } \\
\text { reports, there was no suspected brain } \\
\text { damage, uncorrected sensory } \\
\text { impairment, or other external factors }\end{array}$ & $\begin{array}{l}\text { Total }=1661 \\
\text { boys }=882 \\
\text { girls }=779 \\
\text { 2nd }=452 \\
\text { 3rd }=407 \\
\text { thth }=432 \\
5 \text { th }=370\end{array}$ & $\begin{array}{l}\text { Total }=81 \\
\text { boys }=66 \\
\text { girls }=15 \\
\text { 2nd }=28 \\
\text { 3rd }=13 \\
\text { 4th }=24 \\
5 \text { th }=16\end{array}$ & $\begin{array}{l}\text { Total }=4.88 \% \\
\text { boys }=7.48 \% \\
\text { girls }=1.93 \% \\
\text { 2nd }=6.19 \% \\
\text { 3rd }=3.19 \% \\
\text { 4th }=5.56 \% \\
5 \text { th }=4.32 \%\end{array}$ \\
\hline 55 & Su et al., 2020 & China & $\begin{array}{l}\text { Random } \\
\text { sampling }\end{array}$ & Chinese & Western Pacific & MIC & $\begin{array}{l}\text { Raven's standard progressive matrices } \\
\text { (SPM) }\end{array}$ & $\begin{array}{l}\text { (1) The Chinese score was at the bottom } \\
10 \% \text { of the class; } \\
\text { (2) an IQ score of above } 25 \text { percent on } \\
\text { the SPM test; } \\
\text { (3) no hearing impairment, attention } \\
\text { deficit, hyperactivity disorder, autism } \\
\text { or mood disorders }\end{array}$ & $\begin{array}{l}\text { Total }=624 \\
\text { 3rd }=217 \\
\text { tht }=224 \\
5 \text { th }=183\end{array}$ & $\begin{array}{l}\text { Total }=62 \\
3 \text { rd }=22 \\
4 \text { th }=22 \\
5 \text { th }=18\end{array}$ & $\begin{array}{l}\text { Total }=9.94 \% \\
3 \mathrm{rrd}=10.14 \% \\
4 \mathrm{th}=9.82 \% \\
5 \mathrm{th}=9.84 \%\end{array}$ \\
\hline 56 & YILIZHATI et al., 2020 & China & $\begin{array}{l}\text { Random } \\
\text { sampling }\end{array}$ & Chinese & Western Pacific & MIC & $\begin{array}{l}\text { (1) One-minute word reading test; } \\
\text { (2) Raven's intelligence test }\end{array}$ & $\begin{array}{l}\text { (1) Students whose reading level was } \\
\text { considered by the teacher to be at the } \\
\text { bottom } 25 \% \text { of the classs } \\
\text { (2) the score of "one-minute word } \\
\text { reading test" was } 1 \text { SD lower than the } \\
\text { grade average; } \\
\text { (3) no obvious physical injury, } \\
\text { behavioral and emotional disorders; } \\
\text { (4) an II score of above } 25 \text { percent on } \\
\text { the SPM test }\end{array}$ & Total $=1233$ & Total $=119$ & Total $=9.65 \%$ \\
\hline
\end{tabular}


Study

Omitting Bruininks et al., 1971

Omitting Berger et al., 1975

Omitting Nathlie A. Badian, 1984

Omitting Lindgren et al., 1985 (study1)

Omitting Lindgren et al., 1985 (study2)

Omitting Farrag et al., 1988

Omitting T?nnessen et al., 1993

Omitting Lewis et al., 1994

Omitting Prior et al., 1995

Omitting Zhang et al., 1996

Omitting Miles et al., 1998

Omitting Nathlie A. Badian, 1999

Omitting Flannery et al., 2000

Omitting Lv et al., 2000

Omitting Bhakta et al., 2002

Omitting Yao et al., 2003

Omitting Han Juan, 2005

Omitting Pan et al., 2006

Omitting Song Ranran, 2006

Omitting Yu Yizhen, 2006

Omitting Chan et al., 2007

Omitting Lu Shan, 2007

Omitting Fluss et al., 2008

Omitting Wang Zhong, 2008

Omitting Zou Yuliang, 2008

Omitting Shaheen, H. A., 2010

Omitting Zou et al., 2010

Omitting Daseking et al., 2011

Omitting Jiménez et al., 2011(study1)

Omitting Jiménez et al., 2011(study2)

Omitting Pouretemad et al., 2011

Omitting Vale et al., 2011

Omitting Zhu Dongmei, 2011

Omitting Mogasale et al., 2012

Omitting Luo Yan, 2012

Omitting Zhao Xiaochen, 2013

Omitting Zuo et al., 2013

Omitting Liu et al., 2014

Omitting Irene Jepkoech Cheruiyot, 2015

Omitting Liu et al., 2016

Omitting Padhy et al., 2016

Omitting Sheikh et al., 2016

Omitting Song Yi, 2016

Omitting Zhang et al., 2016

Omitting Zhao et al., 2016

Omitting Cuadro et al., 2017

Omitting Qian Lizhu, 2017

Omitting Wang Rui, 2017

Omitting Yan Nairui, 2018

Omitting Yoo et al., 2018

Omitting Zhou et al., 2018

Omitting Barbiero et al., 2019

Omitting Fan et al., 2019

Omitting Gu et al. 2019

Omitting Zhu et al., 2019

Omitting Cai et al., 2020

Omitting Su et al., 2020

Omitting YILIZHATI et al., 2020

Total $(95 \% \mathrm{CI})$
IV, Random, $95 \% \mathrm{Cl}$

$0.07[0.06 ; 0.08]$

$0.07[0.06 ; 0.08]$

$0.07[0.06 ; 0.08]$

$0.07[0.06 ; 0.08]$

$0.07[0.06 ; 0.08]$

$0.07[0.06 ; 0.08]$

$0.07[0.06 ; 0.08]$

$0.07[0.06 ; 0.08]$

$0.07[0.06 ; 0.08]$

$0.07[0.06 ; 0.08]$

$0.07[0.06 ; 0.08]$

0.07 [0.06; 0.08]

0.07 [0.06; 0.08]

$0.07[0.06 ; 0.08]$

$0.07[0.06 ; 0.08]$

$0.07[0.06 ; 0.08]$

0.07 [0.06; 0.08]

$0.07[0.06 ; 0.08]$

$0.07[0.06 ; 0.08]$

$0.07[0.06 ; 0.08]$

$0.07[0.06 ; 0.08]$

0.07 [0.06; 0.08]

$0.07[0.06 ; 0.08]$

$0.07[0.06 ; 0.08]$

0.07 [0.06; 0.08]

$0.07[0.06 ; 0.08]$

0.07 [0.06; 0.08]

$0.07[0.06 ; 0.08]$

$0.07[0.06 ; 0.08]$

$0.07[0.06 ; 0.08]$

$0.07[0.06 ; 0.08]$

$0.07[0.06 ; 0.08]$

$0.07[0.06 ; 0.08]$

0.07 [0.06; 0.08$]$

0.07 [0.06; 0.08]

$0.07[0.06 ; 0.08]$

$0.07[0.06 ; 0.08]$

$0.07[0.06 ; 0.08]$

0.07 [0.06; 0.08]

0.07 [0.06; 0.08]

$0.07[0.06 ; 0.08]$

0.07 [0.06; 0.08]

$0.07[0.06 ; 0.08]$

$0.07[0.06 ; 0.08]$

$0.07[0.06 ; 0.08]$

$0.07[0.06 ; 0.08]$

$0.07[0.06 ; 0.08]$

$0.07[0.06 ; 0.08]$

0.07 [0.06; 0.08 ]

$0.07[0.06 ; 0.08]$

$0.07[0.06 ; 0.08]$

$0.07[0.06 ; 0.08]$

$0.07[0.06 ; 0.08]$

0.07 [0.06; 0.08]

$0.07[0.06 ; 0.08]$

$0.07[0.06 ; 0.08]$

$0.07[0.06 ; 0.08]$

$0.07[0.06 ; 0.08]$

$0.07[0.06 ; 0.08]$
IV, Random, $95 \% \mathrm{Cl}$

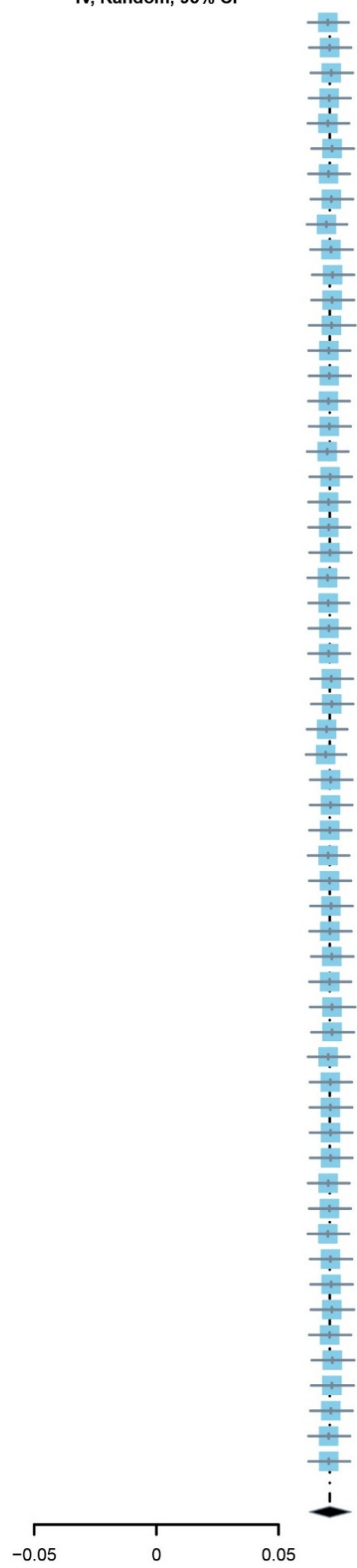

Figure A1. Leave-1-out forest. 


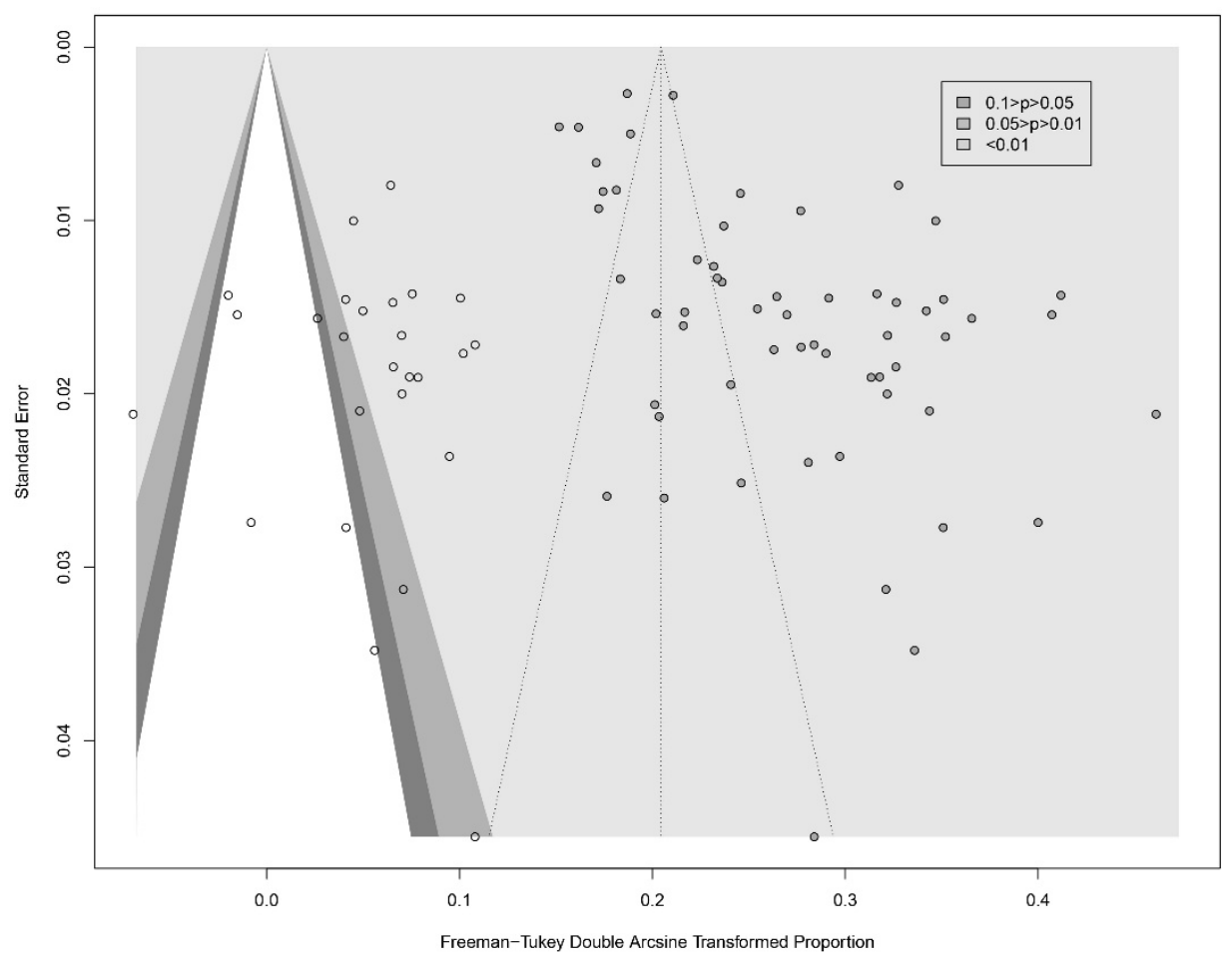

Figure A2. Funnel plot.

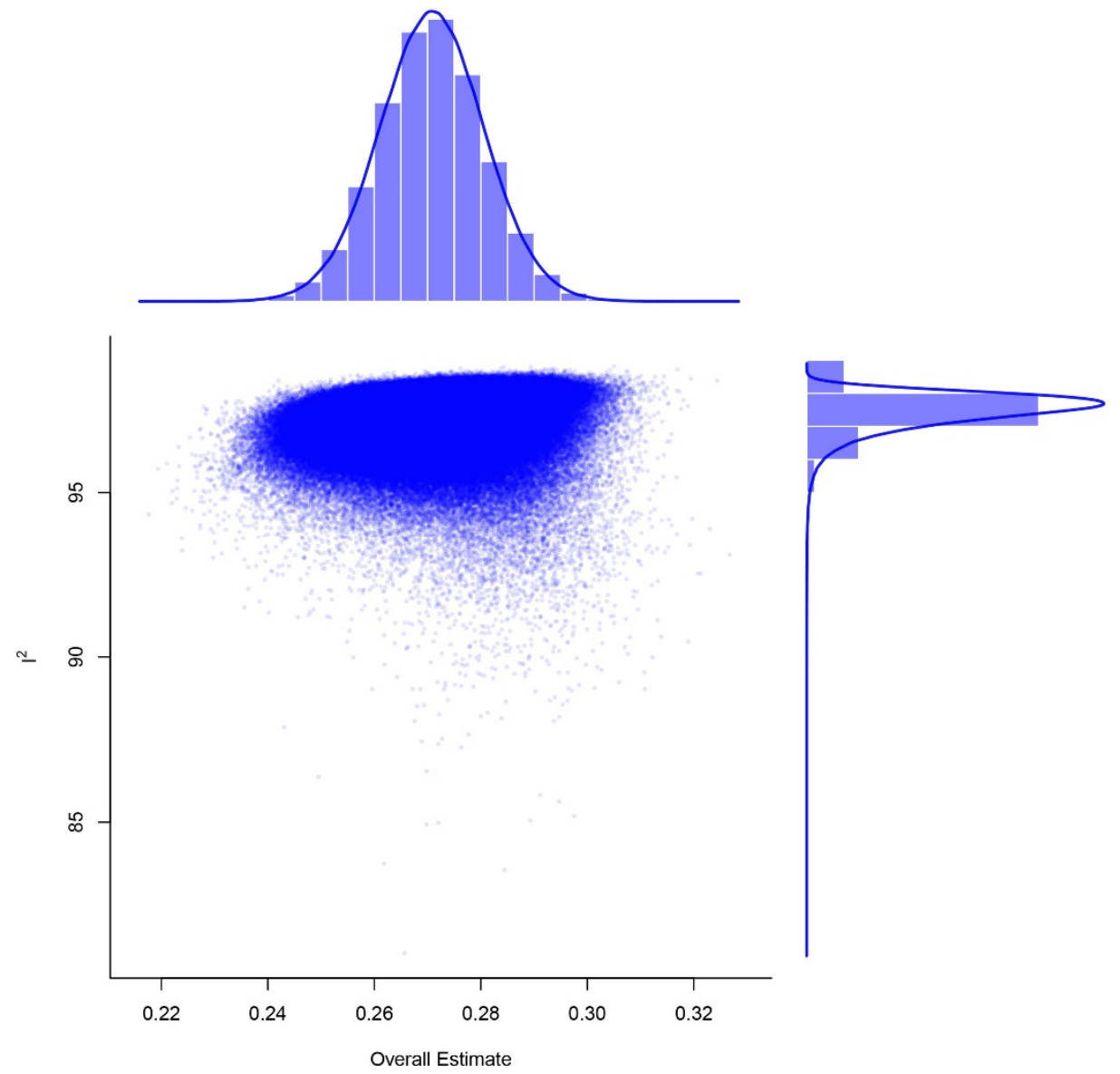

Figure A3. GOSH plot. 


\section{References}

1. American Psychiatric Association. Diagnostic and Statistical Manual of Mental Disorders, 5th ed.; American Psychiatric Publishing: Arlington, VA, USA, 2013

2. World Health Organization. International Statistical Classification of Diseases and Related Health Problems, 10th Revision; World Health Organization: Geneva, Switzerland, 2016.

3. Lerner, J.W. Educational interventions in learning disabilities. J. Am. Acad. Child. Adolesc. Psychiatry 1989, 28, 326-331. [CrossRef] [PubMed]

4. Volkmer, S.; Schulte-Körne, G. Cortical responses to tone and phoneme mismatch as a predictor of dyslexia? A systematic review. Schizophr. Res. 2018, 191, 148-160. [CrossRef] [PubMed]

5. Huntington, D.D.; Bender, W.N. Adolescents with learning disabilities at risk? Emotional well-being, depression, suicide. J. Learn. Disabil. 1993, 26, 159-166. [CrossRef] [PubMed]

6. Tsovili, T.D. The relationship between language teachers' attitudes and the state-trait anxiety of adolescents with dyslexia. J. Res. Read. 2004, 27, 69-86. [CrossRef]

7. Carroll, J.M.; Iles, J.E. An assessment of anxiety levels in dyslexic students in higher education. Br. J. Educ. Psychol. 2006, 76, 651-662. [CrossRef]

8. Casey, R.; Levy, S.E.; Brown, K.; Brooks-Gunn, J. Impaired Emotional Health in Children with Mild Reading Disability. J. Dev. Behav. Pediatr. 1992, 13, 256-260. [CrossRef]

9. Hutton, J.S.; Dewitt, T.; Hoffman, L.; Horowitz-Kraus, T.; Klass, P. Development of an Eco-Biodevelopmental Model of Emergent Literacy before Kindergarten: A Review. JAMA Pediatr. 2021, 175, 730. [CrossRef]

10. Greenberg, D.; Ehri, L.C.; Perin, D. Are word-reading processes the same or different in adult literacy students and third-fifth graders matched for reading level? J. Educ. Psychol. 1997, 89, 262-275. [CrossRef]

11. Liebig, J.; Friederici, A.D.; Neef, N.E.; Friederici, A.D.; Emmrich, F.; Brauer, J.; Wilcke, A.; Neef, N.E.; Boltze, J.; Skeide, M.; et al. Auditory brainstem measures and genotyping boost the prediction of literacy: A longitudinal study on early markers of dyslexia. Dev. Cogn. Neurosci.-Neth. 2020, 46, 100869. [CrossRef]

12. Cheruiyot, I.J. The Prevalence of Dyslexia among Children Aged 7 to 9 in a Nairobi School. Master's Thesis, University of Nairobi, Nairobi, Kenya, 2015.

13. Vellutino, F.R.; Fletcher, J.M.; Snowling, M.J.; Scanlon, D.M. Specific reading disability (dyslexia): What have we learned in the past four decades? J. Child Psychol. Psychol. 2004, 45, 2-40. [CrossRef]

14. Shaywitz, S.E. Dyslexia. N. Engl. J. Med. 1998, 338, 307-312. [CrossRef] [PubMed]

15. Peterson, R.L.; Pennington, B.F. Developmental dyslexia. Lancet 2012, 379, 1997-2007. [CrossRef]

16. Wagner, R.K.; Zirps, F.A.; Edwards, A.A.; Wood, S.G.; Beal, B. The Prevalence of Dyslexia: A New Approach to Its Estimation. J. Learn. Disabil. 2020, 53, 354-365. [CrossRef] [PubMed]

17. Barbiero, C.; Montico, M.; Lonciari, I.; Monasta, L.; Penge, R.; Vio, C.; Tressoldi, P.E.; Carrozzi, M.; Petris, A.D.; Cagno, A.G.D.; et al The lost children: The underdiagnosis of dyslexia in Italy. A cross-sectional national study. PLoS ONE 2019, 14, e210448. [CrossRef]

18. El Sheikh, M.M.; El Missiry, M.A.; Hatata, H.A.; Sabry, W.M.; El Fiky, A.A.A.; Essawi, H.I. Frequency of occurrence of specific reading disorder and associated psychiatric comorbidity in a sample of Egyptian primary school students. Child Adolesc. Ment. Health 2016, 21, 209-216. [CrossRef] [PubMed]

19. Miles, T.R.; Haslum, M.N.; Wheeler, T.J. Gender Ratio in Dyslexia. Ann. Dyslexia 1998, 48, 27-55. [CrossRef]

20. Fluss, J.; Ziegler, J.; Ecalle, J.; Magnan, A.; Warszawski, J.; Ducot, B.; Richard, G.; Billard, C. Prevalence of reading disabilities in early elementary school: Impact of socioeconomic environment on reading development in 3 different educational zones. Arch. Pediatr. 2008, 15, 1049-1057. [CrossRef]

21. Prior, M.; Sanson, A.; Smart, D.; Oberklaid, F. Reading disability in an Australian community sample. Aust. J. Psychol. 1995, 47, 32-37. [CrossRef]

22. Jiménez, J.E.; de la Cadena, C.G.; Siegel, L.S.; O’Shanahan, I.; García, E.; Rodríguez, C. Gender ratio and cognitive profiles in dyslexia: A cross-national study. Read. Writ. 2011, 24, 729-747. [CrossRef]

23. Kuo, L.; Anderson, R.C. Morphological Awareness and Learning to Read: A Cross-Language Perspective. Educ. Psychol. 2006, 41, 161-180. [CrossRef]

24. Anderson, R.C.; Li, W.; Ku, Y.-M.; Shu, H.; Wu, N. Use of partial information in learning to read Chinese characters. J. Educ. Psychol. 2003, 95, 52-57. [CrossRef]

25. Hu, W.; Lee, H.L.; Zhang, Q.; Liu, T.; Geng, L.B.; Seghier, M.L.; Shakeshaft, C.; Twomey, T.; Green, D.W.; Yang, Y.M.; et al. Developmental dyslexia in Chinese and English populations: Dissociating the effect of dyslexia from language differences. Brain 2010, 133, 1694-1706. [CrossRef] [PubMed]

26. Caravolas, M. The Nature and Causes of Dyslexia in Different Languages. In The Science of Reading: A Handbook; Snowling, M.J., Hulme, C., Eds.; Blackwell Publishing Ltd.: Oxford, UK, 2005; pp. 336-355.

27. Stevenson, H.W.; Stigler, J.W.; Lucker, G.W.; Lee, S.; Hsu, C.; Kitamura, S. Reading Disabilities: The Case of Chinese, Japanese, and English. Child. Dev. 1982, 53, 1164. [CrossRef]

28. Katz, L.; Frost, R. Reading in different orthographies: The orthographic depth hypothesis. In Orthography, Phonology, Morphology, and Meaning; Frost, R., Katz, L., Eds.; Elsevier North Holland Press: Amsterdam, The Netherlands, 1992; pp. 67-84. 
29. Ziegler, J.C.; Goswami, U. Reading acquisition, developmental dyslexia, and skilled reading across languages: A psycholinguistic grain size theory. Psychol. Bull. 2005, 131, 3-29. [CrossRef] [PubMed]

30. Seidenberg, M.S. Reading in different writing systems: One architecture, multiple solutions. In Dyslexia across Languages: Orthography and the Brain-Gene-Behavior Link; McCardle, P., Miller, B., Lee, J.R., Tzeng, O.J.L., Eds.; Paul H Brookes Publishing: Baltimore, MD, USA, 2011; pp. 146-168.

31. Cuadro, A.; von Hagen, A.; Costa Ball, D. Procedural differences in the calculation of the prevalence of reading difficulties in Spanish-speaking school children/Diferencias procedimentales en el cálculo de la prevalencia del retraso lector en escolares hispanoparlantes. Estudios de Psicología 2017, 38, 169-197. [CrossRef]

32. De Groot, B.J.; Van den Bos, K.P.; Van der Meulen, B.F.; Minnaert, A.E. Rapid Naming and Phonemic Awareness in Children With Reading Disabilities and/or Specific Language Impairment: Differentiating Processes? J. Speech Lang. Hear. Res. 2015, 58, 1538-1548. [CrossRef] [PubMed]

33. Shaheen, H.A. Reversing Letters, Asymmetric Tonic Neck, Neck Retraction Reflexes and Apraxia are Predictive of Dyslexia. Egypt. J. Neurol. Psychiatry Neurosurg. 2010, 47, 453-459.

34. Berger, M.; Yule, W.; Rutter, M. Attainment and adjustment in two geographical areas. II-The prevalence of specific reading retardation. Br. J. Psychiatry 1975, 126, 510-519. [CrossRef]

35. Liu, L.F.; Wang, J.; Shao, S.S.; Luo, X.; Kong, R.; Zhang, X.H.; Song, R.R. Descriptive epidemiology of prenatal and perinatal risk factors in a Chinese population with reading disorder. Sci. Rep. 2016, 6, 36697. [CrossRef]

36. Bhakta, P.; Hackett, R.J.; Hackett, L. The prevalence and associations of reading difficulties in a population of South Indian children. J. Res. Read. 2002, 25, 191-202. [CrossRef]

37. Shaywitz, S.E.; Morris, R.; Shaywitz, B.A. The education of dyslexic children from childhood to young adulthood. Annu. Rev. Psychol. 2008, 59, 451-475. [CrossRef] [PubMed]

38. Page, M.J.; McKenzie, J.E.; Bossuyt, P.M.; Boutron, I.; Hoffmann, T.C.; Mulrow, C.D.; Shamseer, L.; Tetzlaff, J.M.; Akl, E.A.; Brennan, S.E.; et al. The PRISMA 2020 statement: An updated guideline for reporting systematic reviews. BMJ 2021, 372 , n71. [CrossRef] [PubMed]

39. von Elm, E.; Altman, D.G.; Egger, M.; Pocock, S.J.; Gøtzsche, P.C.; Vandenbroucke, J.P. The Strengthening the Reporting of Observational Studies in Epidemiology (STROBE) Statement: Guidelines for Reporting Observational Studies. Ann. Intern. Med. 2007, 147, 573. [CrossRef] [PubMed]

40. Barendregt, J.J.; Doi, S.A.; Lee, Y.Y.; Norman, R.E.; Vos, T. Meta-analysis of prevalence. J. Epidemiol. Commun. Health 2013, 67, 974-978. [CrossRef] [PubMed]

41. Higgins, J.P.T. Measuring inconsistency in meta-analyses. BMJ 2003, 327, 557-560. [CrossRef]

42. Higgins, J.P.T.; Thompson, S.G. Quantifying heterogeneity in a meta-analysis. Stat. Med. 2002, 21, 1539-1558. [CrossRef]

43. Wallace, B.C.; Schmid, C.H.; Lau, J.; Trikalinos, T.A. Meta-Analyst: Software for meta-analysis of binary, continuous and diagnostic data. BMC Med. Res. Methodol. 2009, 9, 80. [CrossRef]

44. Egger, M.; Smith, G.D.; Schneider, M.; Minder, C. Bias in meta-analysis detected by a simple, graphical test. BMJ 1997, 315, 629-634. [CrossRef]

45. Begg, C.B.; Mazumdar, M. Operating Characteristics of a Rank Correlation Test for Publication Bias. Biometrics 1994, 50, $1088-1101$. [CrossRef]

46. Peters, J.L.; Sutton, A.J.; Jones, D.R.; Abrams, K.R.; Rushton, L. Comparison of Two Methods to Detect Publication Bias in Meta-analysis. JAMA 2006, 295, 676-680. [CrossRef]

47. Viechtbauer, W. Conducting Meta-Analyses in R with the metafor Package. J. Stat. Softw. 2010, 36, 1-48. [CrossRef]

48. Baranyi, G.; Scholl, C.; Fazel, S.; Patel, V.; Priebe, S.; Mundt, A.P. Severe mental illness and substance use disorders in prisoners in low-income and middle-income countries: A systematic review and meta-analysis of prevalence studies. Lancet Glob. Health 2019, 7, e461-e471. [CrossRef]

49. Song, P.G.; Zhang, Y.; Yu, J.Y.; Zha, M.M.; Zhu, Y.J.; Rahimi, K.; Rudan, I. Global Prevalence of Hypertension in Children: A Systematic Review and Meta-analysis. JAMA Pediatr. 2019, 173, 1154-1163. [CrossRef] [PubMed]

50. Shaywitz, S.E.; Escobar, M.D.; Shaywitz, B.A.; Fletcher, J.M.; Makuch, R. Evidence That Dyslexia May Represent the Lower Tail of a Normal Distribution of Reading Ability. N. Engl. J. Med. 1992, 326, 145-150. [CrossRef] [PubMed]

51. Saviour, P.; Padakannaya, P.; Nishanimutt, S.; Ramachandra, N.B. Familial Patterns and Biological Markers of Dyslexia. Int. J. Hum. Genet. 2009, 9, 21-29. [CrossRef]

52. Shaywitz, S.E.; Shaywitz, B.A.; Fletcher, J.M.; Escobar, M.D. Prevalence of reading disability in boys and girls. Results of the Connecticut Longitudinal Study. JAMA 1990, 264, 998-1002. [CrossRef]

53. Rutter, M.; Caspi, A.; Fergusson, D.; Horwood, L.J.; Goodman, R.; Maughan, B.; Moffitt, T.E.; Meltzer, H.; Carroll, J. Sex Differences in Developmental Reading Disability. JAMA 2004, 291, 2007. [CrossRef]

54. Zhang, B.P.; Zhao, H.; Chen, Y.; Zhou, X.; Zuo, P.X. Research on environmental influencing factors of Uygur children with developmental dyslexia. Chin. J. Sch. Health 2016, 37, 325-327.

55. Qian, L.Z. The Research on the Relationship between the Self-Esteem of Dyslexic Children and Loneliness and Social Anxiety. Master's Thesis, Northwest Normal University, Lanzhou, China, 2017. 
56. Christopher, M.E.; Hulslander, J.; Byrne, B.; Samuelsson, S.; Keenan, J.M.; Pennington, B.; DeFries, J.C.; Wadsworth, S.J.; Willcutt, E.; Olson, R.K. The genetic and environmental etiologies of individual differences in early reading growth in Australia, the United States, and Scandinavia. J. Exp. Child Psychol. 2013, 115, 453-467. [CrossRef]

57. Logan, J.A.; Hart, S.A.; Cutting, L.; Deater-Deckard, K.; Schatschneider, C.; Petrill, S. Reading Development in Young Children: Genetic and Environmental Influences. Child Dev. 2013, 84, 2131-2144. [CrossRef]

58. Nass, R. Sex Differences in Learning Abilities and Disabilities. Ann. Dyslexia 1993, 43, 61-77. [CrossRef]

59. Liederman, J.; Kantrowitz, L.; Flannery, K. Male vulnerability to reading disability is not likely to be a myth: A call for new data. J. Learn. Disabil. 2005, 38, 109-129. [CrossRef] [PubMed]

60. Tønnessen, F.E.; Løkken, A.; Høien, T.; Lundberg, I. Dyslexia, left-handedness, and immune disorders. Arch. Neurol. 1993, 50, 411. [CrossRef] [PubMed]

61. Su, L.Y.; Yan, X.F.; Lu, H.D. A Comparative Study of the Component Model and the Discrepancy Model in the Diagnosis of Reading Dyslexia. J. Mod. Spec. Educ. 2020, 4, 72-77.

62. Flannery, K.A.; Liederman, J.; DALY, L.; Schultz, J. Male prevalence for reading disability is found in a large sample of Black and White children free from ascertainment bias. J. Int. Neuropsych. Soc. 2000, 6, 433-442. [CrossRef]

63. Gu, H.T.; Zhu, B.; Hou, F.; Xie, X.Y.; Xue, Q.; Li, X.; Song, R.R. Association of learning and living style with dyslexia in school-aged children. Chin. J. Sch. Health 2019, 40, 1137-1140.

64. Mansukhani, K.; Barretto, M.; Donde, S.; Wandrekar, J.; Nigudkar, A.; Nair, R. Epidemiological survey of neurological diseases in a tribal population cluster in Gujarat. Ann. Indian Acad. Neurol. 2018, 21, 294-299.

65. Eliasen, E.H.; Ferrer, M.; Gaini, S.; Louis, E.D.; Petersen, M.S. Prevalence of Essential Tremor in the Faroe Islands: A PopulationBased Study. Neuroepidemiology 2019, 52, 227-236. [CrossRef]

66. Zhao, H.; Zhang, B.P.; Chen, Y.; Zhou, X.; Zuo, P.X. Environmental Risk Factors in Han and Uyghur Children with Dyslexia: A Comparative Study. PLoS ONE 2016, 11, e159042. [CrossRef]

67. Ollikainen, M.; Smith, K.R.; Joo, E.J.H.; Ng, H.K.; Andronikos, R.; Novakovic, B.; Aziz, N.K.A.; Carlin, J.B.; Morley, R.; Saffery, R.; et al. DNA methylation analysis of multiple tissues from newborn twins reveals both genetic and intrauterine components to variation in the human neonatal epigenome. Hum. Mol. Genet. 2010, 19, 4176-4188. [CrossRef]

68. Pouretemad, H.R.; Khatibi, A.; Zarei, M.; Stein, J. Manifestations of developmental dyslexia in monolingual Persian speaking students. Arch. Iran. Med. 2011, 14, 259-265. [PubMed]

69. Shao, S.S. Research on the Roles of Genes in the Neuronal Migration and Outgrowth Network for Chinese Developmental Dyslexia. Ph.D. Thesis, Huazhong University of Science and Technology, Wuhan, China, 2016.

70. Zuo, P.X.; Gu, Q.; Li, Z.C.; Jiao, P.P.; Zhang, J. Influence factor analysis of Uighur children with dyslexia. Chin. J. Child Health Care 2013, 21, 1254-1255.

71. Zhu, D.M. Executive Functions for Chinese Developmental Dyslexia Children. Ph.D. Thesis, Huazhong University of Science and Technology, Wuhan, China, 2011.

72. Olkin, I.; Dahabreh, I.J.; Trikalinos, T.A. GOSH_A graphical display of study heterogeneity. Res. Synth. Methods 2012, 3, 214-223. [CrossRef] [PubMed]

73. Peterson, R.L.; Pennington, B.F. Developmental dyslexia. Annu. Rev. Clin. Psychol. 2015, 11, 283-307. [CrossRef]

74. MacDonald Wer, B.M. Comparison of Reading Development across Socioeconomic Status in the United States. Ph.D. Thesis, University of Denver, Denver, CO, USA, 2014. 